\title{
Highway to Success: The Impact of the Golden Quadrilateral Project for the Location and Performance of Indian Manufacturing
}

\section{Citation}

Ghani, Ejaz, Arti Grover Goswami, and William R. Kerr. "Highway to Success: The Impact of the Golden Quadrilateral Project for the Location and Performance of Indian Manufacturing." Harvard Business School Working Paper, No. 13-040, November 2012. (NBER Working Paper Series, No. 18524, November 2012.)

\section{Permanent link}

http://nrs.harvard.edu/urn-3:HUL.InstRepos:10208238

\section{Terms of Use}

This article was downloaded from Harvard University's DASH repository, and is made available under the terms and conditions applicable to Open Access Policy Articles, as set forth at http:// nrs.harvard.edu/urn-3:HUL.InstRepos:dash.current.terms-of-use\#OAP

\section{Share Your Story}

The Harvard community has made this article openly available.

Please share how this access benefits you. Submit a story.

\section{Accessibility}


H A R VARD D B U I N E S S S C H O O L

Highway to Success:

The Impact of the Golden

Quadrilateral Project for the

Location and Performance of

Indian Manufacturing

Ejaz Ghani

Arti Grover Goswami

William R. Kerr

Working Paper

13-040

November 8, 2012 


\title{
Highway to Success: The Impact of the Golden Quadrilateral Project for the Location and Performance of Indian Manufacturing
}

\author{
Ejaz Ghani, Arti Grover Goswami, and William R. Kerr
}

November 2012

\begin{abstract}
We investigate the impact of the Golden Quadrilateral (GQ) highway project on the Indian organized manufacturing sector using enterprise data. The GQ project upgraded the quality and width of $5,846 \mathrm{~km}$ of roads in India. We use a difference-in-difference estimation strategy to compare non-nodal districts based upon their distance from the highway system. We find several positive effects for nonnodal districts located 0-10 km from GQ that are not present in districts 10-50 km away, most notably higher entry rates and increases in plant productivity. These results are not present for districts located on another major highway system, the North-South East-West corridor (NS-EW). Improvements for portions of the NS-EW system were planned to occur at the same time as GQ but were subsequently delayed. Additional tests show that the GQ project's effect operates in part through a stronger sorting of landintensive industries from nodal districts to non-nodal districts located on the GQ network. The GQ upgrades further helped spread economic activity to moderate-density districts and intermediate cities.
\end{abstract}

Keywords: Highways, roads, infrastructure, India, development, manufacturing, density, rent.

JEL Classification: L10, L25, L26, L60, L80, L90, L91, L92, M13, O10, R00, R10, R11, R14

Author institutions and contact details: Ghani: World Bank, Eghani@worldbank.org; Grover Goswami: World Bank, agrover1@worldbank.org; Kerr: Harvard University, Bank of Finland, and NBER, wkerr@hbs.edu.

Acknowledgments: We are grateful to Partha Mukhopadhyay, Stephen O'Connell, Hyoung Gun Wang and seminar participants for helpful suggestions/comments. We are particularly indebted to Sarah Elizabeth Antos and Henry Jewell for excellent data work and maps. We thank the World Bank's South Asia Labor Flagship team for providing the primary datasets used in this paper. Funding for this project was provided by a Private Enterprise Development in Low-Income Countries grant by the Centre or Economic Policy Research and by World Bank's Multi-Donor Trade Trust Fund. Kerr was a paid short-term contractor of the World Bank for this project. The views expressed here are those of the authors and not of any institution they may be associated with. 


\section{Section 1: Introduction}

Adequate transportation infrastructure is an essential ingredient for economic development and growth. Beyond simply facilitating cheaper and more efficient movements of goods, people, and ideas across places, transportation infrastructure impacts the distribution of economic activity and development across regions, the extent to which agglomeration economies and efficient sorting can be realized, the levels of competition among industries and concomitant reallocation of inputs towards productive enterprises, and much more. Rapidly expanding countries like India and China often face severe constraints on their transportation infrastructure. Many business leaders, policy makers, and academics describe infrastructure as a critical hurdle for sustained growth that must be met with public funding, but to date we have a very limited understanding of the economic impact of those projects.

We study the impact of the Golden Quadrilateral (GQ) project, a large-scale highway construction and improvement project in India. The GQ project sought to improve the connection of four major cities in India: Delhi, Mumbai, Chennai, and Kolkata. The GQ system comprises 5,846 km (3,633 mi) of road connecting many of the major industrial, agricultural, and cultural centers of India. It is the fifth-longest highway in the world. The massive project began in 2001, was two-thirds complete by 2005, and mostly finished in 2007. Datta (2011), a study that we describe in greater detail below, finds that GQ upgrades quickly improved the inventory management and sourcing choices of manufacturing plants located in non-nodal districts along the GQ network by 2005.

This paper investigates the impact of the GQ highway upgrades on the organization and performance of the organized manufacturing sector for India. Several studies evaluate the performance of Indian manufacturing, especially after the liberalization reforms (e.g. Kochhar et al. 2006, Ahluwalia 2000, Besley and Burgess 2004). Some authors argue that Indian manufacturing has been constrained by inadequate infrastructure and that industries that are dependent upon infrastructure have not been able to reap the maximum benefits of the liberalization's reforms (e.g. Gupta et al. 2008, Gupta and Kumar 2010, Mitra et al. 1998).

We employ plant-level data from the years 1994, 2000, 2005, and 2007 to study the impact of highway infrastructure investments on Indian manufacturing. We study how proximity to GQ in non-nodal districts affected the organization of manufacturing activity using establishment counts, employment, and output levels, especially among newly entering plants that are making location choice decisions before or after the upgrades. This work on the organization of the manufacturing sector also considers industry-level 
sorting and the extent to which intermediate cities in India are becoming more attractive for manufacturing plants. We study the impact for the sector's performance through measures of average labor productivity and total factor productivity (TFP).

Our work exploits several forms of variation to identify the effects. First, our data include two surveys before and after the upgrades, which allows us to exploit pre-post variation for the GQ upgrades. Second, we use GIS software to code how far districts are from the GQ network. Throughout this paper, we measure effects for nodal districts in the GQ network, but we do not ascribe a causal interpretation to these effects because the GQ upgrades were in large part designed to improve the connections of these hubs and the GQ upgrade decision may have been endogenous to the growth prospects of these hubs. Instead, our key focus is on non-nodal districts that are very close to the GQ network compared to those that are farther away. We specifically compare non-nodal districts $0-10 \mathrm{~km}$ from the GQ network to districts 10-50 km away (and in some specifications with additional concentric rings to $200 \mathrm{~km}$ away). Additional sources of variation come from the sequence in which districts were upgraded, differences in industry traits within the manufacturing sector, and differences in the traits of non-nodal districts 0-10 km from the GQ network.

We find generally positive effects of the GQ upgrades on the organized manufacturing sector. Panel estimations find substantial growth in entry rates in non-nodal districts within $10 \mathrm{~km}$ of the GQ network after the GQ upgrades. These patterns are absent in districts 10-50 km away, and the data suggest that there might have even been declines in entry rates in districts farther away (perhaps indicative of a more substantial shift of activity towards the GQ network due to the improved connectivity). Heightened entry rates are evident in districts where the GQ project upgraded existing highways and where the GQ project constructed new highways where none existed before.

Beyond entry rates, we find positive but statistically insignificant impacts for the total level of manufacturing activity across all districts within $10 \mathrm{~km}$ of the GQ network. There is greater heterogeneity on this dimension, however, with the construction of new highways being associated with aggregate activity gains. As we discuss, the limited impact for upgrades of existing highways for total activity could be due to the fact that our sample end point in 2007 is not sufficiently removed from the GQ upgradessuch that we can observe the marginal entry decisions but not the long-term consequences of these decisions for business locations. The differences could also be due to higher exit rates for incumbents in the area. While we can observe new firms with our data, we are unfortunately limited with respect to measuring the exit margin. 
In terms of performance, panel estimations show a substantial increase in labor productivity and TFP among manufacturing plants in non-nodal districts within $10 \mathrm{~km}$ of the GQ network that is not present in districts that are 10-50 km removed or farther.

Beyond the variation afforded by distance of districts from the GQ network, we undertake two additional exercises that indicate these changes in district outcomes are mostly linked to the GQ upgrades. First, we examine dynamic panel estimations. For our entry results, these dynamic models do not find a lead effect in non-nodal districts prior to the GQ upgrades. These specifications suggest that the timing of the improvements in the manufacturing sector is closely tied to the timing of the improvements in the GQ network. On the other hand, for our productivity results, we observe a dip in performance in the 2000 period before the GQ upgrades for non-nodal districts that may suggest our productivity results are in part capturing a rebound in activity from this decline that is not linked to the GQ upgrades. As a second approach, we separate districts by when the GQ upgrades were completed. Differences in coefficient magnitudes by implementation date are again consistent with the economic effects we measure being due to the GQ improvements.

Second, India has a second major highway network called the North-South East-West (NS-EW) highway. The NS-EW highway was scheduled for a partial upgrade at the same time as the GQ network, but this upgrade was delayed. The upgrade has since been undertaken. Comparisons of non-nodal districts on GQ to non-nodal districts on NS-EW are attractive given the comparable initial condition of being located on a major transportation network. Moreover, the government intended to start upgrading the NS-EW highway network, albeit on a somewhat smaller scale, at the same time as the GQ upgrades. We do not find similar effects along the NS-EW highway system that we observe along the GQ highway system for either our entry or performance results, which is comforting for experimental design.

Building from these exercises, we next study the extent to which the GQ upgrades influenced the organization of manufacturing activity. We find that the heightened entry rates following the GQ upgrades in non-nodal districts within $10 \mathrm{~km}$ of the GQ network were strongest in industries that are very land and building intensive. Interestingly, we find the opposite pattern for nodal districts, where the shift is towards industries that are less intensive in land and buildings. These intuitive patterns are suggestive evidence that the GQ upgrades improved the spatial allocation of activity in India, similar to improvements in within-district spatial allocation due to infrastructure observed by Ghani et al. (2012). Looking at differences in district density, the effects of GQ upgrades are evident in districts with high and 
medium density, but are weak in districts with low density. The medium-density findings may suggest that GQ upgrades helped activate intermediate cities, where some observers believe India's development has underperformed compared to China.

Our project contributes to the literature on the economic impacts of transportation networks in developing economies, which is unfortunately quite small relative to its policy importance. The closest related study is Datta (2011), who evaluates the impact of GQ upgrades using inventory management questions contained in the World Bank's Enterprise Surveys for India in the years 2002 and 2005. Even with the short time window of three years, Datta (2011) finds that firms located in non-nodal districts along the GQ network witnessed a larger decline in the average input inventory (measured in terms of the number of days of production for which the inventory held was sufficient) relative to those located on other highways. He also finds that firms in districts closer to the GQ network were more likely to switch their primary input suppliers vis-à-vis firms farther away. These results suggest improved efficiency and sourcing for establishments on the GQ network after its upgrade.

Beyond India, several recent studies find positive economic effects in non-nodal locations due to transportation infrastructure in China (e.g., Banerjee et al. 2012, Roberts et al. 2012, Baum-Snow et al. 2012). These studies complement the larger literature on the United States (e.g., Fernald 1998, Chandra and Thompson 2000, Michaels 2008, Duranton and Turner 2012, Baum-Snow 2007, Lahr et al. 2005) ${ }^{1}$, those undertaken in historical settings (e.g., Donaldson 2010, Donaldson and Hornbeck 2012), and those focusing on other developing or emerging economies (e.g., Brown et al. 2008, Ulimwengu et al. 2009). A related literature considers non-transportation infrastructure investments in developing economies (e.g., Duflo and Pande 2007, Dinkelman 2011). ${ }^{2}$

Recent papers in these literatures have grappled with concerns regarding the endogenous placement of infrastructure that prevents a causal interpretation of infrastructure's role. As Duranton and Turner (2011) highlight, the endogenous placement could bias findings in either direction. Infrastructure investments may be made to encourage development of regions with high growth potential, which would upwardly

\footnotetext{
${ }^{1}$ The impact of highways has been studied for other developed countries as well. For example, Holl and ViladecansMarsal (2011) study the impact of highways on Spanish cities while Hsu and Zhang (2011) work with Japanese data.

${ }^{2}$ More broadly, a number of studies find high elasticities of private output with respect to public capital, often greater than 0.3 , but some more disaggregated studies cast some doubt on these elasticities by observing that infrastructure has not been necessarily related to productivity in sectors that should have benefited the most. See, for example, Aschauer (1989), Munnell (1990), and Otto and Voss (1994).
} 
bias measurements of economic effects that do not control for this underlying potential. However, there are many cases where infrastructure investments are made to try to turn around and preserve struggling regions. They may also be directed through the political process towards non-optimal locations (i.e., "bridges to nowhere"). These latter scenarios would downward bias results.

The most prominent identification technique in this work is the use of historical transportation networks or straight lines between nodal cities to predict whether or not a major transportation route exists. ${ }^{3}$ This approach helps us understand the importance of transportation networks in terms of their existence, but it does not help policy makers evaluate the likely impact from investments into improving existing networks. The sums of this latter type of investment are very large and growing. Through 2006 and inclusive of the GQ upgrades, India invested US\$71 billion for the National Highways Development Program to upgrade, rehabilitate, and widen India's major highways to international standards. A recent Committee on Estimates report for the Ministry of Roads, Transport and Highways suggests an ongoing investment need for Indian highways of about US\$15 billion annually for the next 15 to 20 years (The Economic Times, April 29, 2012). Our panel analysis allows us to shed new light on these important questions, with the dynamic models and the comparison to the NS-EW highway preserving counterfactual scenarios as best possible.

The remainder of this paper is as follows: Section 2 gives a synopsis of highways in India and the GQ Project. Section 3 describes the data used for this paper and its development. Section 4 presents the empirical work of the paper, determining the impact of highway improvements on economic activity. Section 5 concludes.

\section{Section 2: India's Highways and the Golden Quadrilateral Project}

Road transport is the principal mode of movement of goods and people in India, accounting for $65 \%$ of freight movement and $80 \%$ of passenger traffic. The road network in India has three categories: (i) national highways that serve interstate long-distance traffic; (ii) state highways and major district roads that carry mainly intrastate traffic; and (iii) district and rural roads that carry mainly intra-district traffic. As of January 2012, India possessed 71,972 km of national highways and expressways and 3.25 million

\footnotetext{
${ }^{3}$ Donaldson (2010) rules out spurious effects in estimating the impact of railroad construction in India by evaluating the hypothetical effects of four railroad lines that were planned but never actually built.
} 
$\mathrm{km}$ of secondary and tertiary roads. While national highways constitute about $1.7 \%$ of the road network, they carry more than $40 \%$ of the total traffic volume. ${ }^{4}$

To meet its transportation needs, India launched its National Highways Development Project (NHDP) in 2001. This project, the largest highway project ever undertaken by India, aimed at improving the Golden Quadrilateral (GQ) network, the North-South and East-West (NS-EW) Corridors, Port Connectivity, and other projects in several phases. The total length of national highways planned to be upgraded (i.e., strengthened and expanded to four lanes) under the NHDP was 13,494 km; the NHDP also sought to build 1,500 km of new expressways with six or more lanes and 1,000 km of other new national highways, including road connectivity to the major ports in the country. Thus, in a majority of cases, the NHDP sought to upgrade a basic infrastructure that existed, rather than build infrastructure where none previously existed. ${ }^{5}$

The NHDP has evolved to include seven different phases, and our paper focuses on the first two stages. NHDP Phase I was approved in December 2000 at an estimated cost of Rs 30,300 crore (1999 prices). Phase I planned to improve 5,846 km of the GQ network, $981 \mathrm{~km}$ of NS-EW, $356 \mathrm{~km}$ of Port Connectivity, and $315 \mathrm{~km}$ of other national highways, for a total improvement of 7,498 km. Phase II was approved in December 2003 at an estimated cost of Rs 34,339 crore (2002 prices). This phase planned to improve $6,161 \mathrm{~km}$ of NS-EW and $486 \mathrm{~km}$ of other national highways, for a total improvement of 6,647 $\mathrm{km}$. About $442 \mathrm{~km}$ length of highway is common between GQ and NS-EW.

The GQ network, totaling a length of $5,846 \mathrm{~km}$, connects the four major cities of Delhi, Mumbai, Chennai, and Kolkata. Figure 1 provides a map of the GQ network. Beyond the four major cities that the GQ network connects, the highway touches many smaller cities like Dhanbad in Bihar, Chittaurgarh in Rajasthan, and Guntur in Andhra Pradesh. The GQ upgrades began in 2001, with a target completion date

\footnotetext{
${ }^{4}$ Source: National Highway Authority of India website: http://www.nhai.org/. The Committee on Infrastructure continues to project that the growth in demand for road transport in India will be 1.5-2 times faster than that for other modes. Available at: http://www.infrastructure.gov.in. By comparison, highways constitute 5\% of the road network in Brazil, Japan, and the United States and 13\% in Korea and the United Kingdom (World Road Statistics 2009).

${ }^{5}$ The GQ program in particular sought to upgrade highways to international standards of four- or six-laned, dualcarriageway highways with grade separators and access roads. In 2002, this group was only $4 \%$ of India's highways, and the GQ work raised this share to $12 \%$ by the end of 2006 .
} 
of 2004. To complete the GQ upgrades, 128 separate contracts were awarded. In total, $23 \%$ of the work was completed by the end of $2002,80 \%$ by the end of $2004,95 \%$ by the end of 2006 , and $98 \%$ by the end of 2010. Differences in completion points were due to initial delays in awarding contracts, land acquisition and zoning challenges, funding delays, ${ }^{6}$ and related contractual problems. Some have also observed that India's construction sector was not fully prepared for a project of this scope. As of August 2011, the cost of the GQ upgrades was about US\$6 billion (1999 prices), about half of the initial estimates.

The NS-EW network, with an aggregate span of 7,300 km, is also shown in Figure 1. This network connects Srinagar in the north to Kanyakumari in the south, and Silchar in the east to Porbandar in the west. The NS-EW upgrades were initially planned to begin in Phase I of NHDP along with the GQ upgrades. The scope of the first phase of upgrades was smaller at $981 \mathrm{~km}$, or $13 \%$ of the total network, with the remainder originally planned to be completed by 2007. However, work on the NS-EW corridor was pushed into Phase II and later, due to issues with land acquisition, zoning permits, and similar. In total, $2 \%$ of the work was completed by the end of $2002,4 \%$ by the end of 2004 , and $10 \%$ by the end of 2006. These figures include the overlapping portions with the GQ network that represent about $40 \%$ of the NS-EW progress by 2006. Since then, the planned upgrades for the NS-EW have expanded substantially. As of January 2012, 5,945 of the 7,300 kilometers in the project have been completed, at an estimated cost of US\$12 billion.

\section{Section 3: Data Preparation}

We employ repeated cross-sectional surveys of manufacturing establishments carried out by the government of India. Our work studies surveys that were conducted in fiscal years 1994, 2000, 2005, and 2007 for the organized sector. In all cases, the survey was undertaken over two fiscal years (e.g., the 1994 survey was conducted during 1994-1995), but we will only refer to the initial year for simplicity. This time span allows us two surveys before and after the GQ upgrades. This section describes some key features of these data for our study. ${ }^{7}$

\footnotetext{
${ }^{6}$ The initial two phases were about $90 \%$ publicly funded and focused on regional implementation. The NHDP allows for public-private partnerships, which it hopes will become a larger share of future development.

${ }^{7}$ For additional detail on the manufacturing survey data, see Nataraj (2011), Kathuria et al. (2010), Fernandes and Pakes (2008), Hasan and Jandoc (2010), and Ghani et al. (2011).
} 
It is important to first define the organized manufacturing sector of the Indian economy. The organized manufacturing sector is comprised of establishments with more than ten workers if the establishment uses electricity. If the establishment does not use electricity, the threshold is 20 workers or more. These establishments are required to register under the India Factories Act of 1948. The unorganized manufacturing sector is, by default, comprised of establishments which fall outside the scope of the Factories Act. The organized sector accounts for over $80 \%$ of India's manufacturing output, while the unorganized sector accounts for a high share of plants and employment (Ghani et al. 2012). We focus on the organized sector in this study.

The organized manufacturing sector is surveyed by the Central Statistical Organization through the Annual Survey of Industries (ASI). Establishments are surveyed with state and four-digit National Industry Classification (NIC) stratification. We use the provided sample weights to construct populationlevel estimates of organized manufacturing activity at the district and two-digit NIC level. Districts are administrative subdivisions of Indian states or union territories. As we discuss further below, we use district variation to provide more granular distances from the various highway networks.

ASI surveys record several economic characteristics of plants like employment, output, capital, raw materials, and land and building value. For measures of total manufacturing activity in locations, we aggregate the activity of plants up to the district or district-industry level. We also develop measures of labor productivity and TFP. Labor productivity is measured through output per employee at the plant level, with an average then taken across plants for a district. TFP is calculated through a residual regression approach. For every two-digit NIC industry and year, we regress log value-added (output minus raw materials) of plants on their log employment and log capital. The residual from this regression for each plant is taken as its TFP. We then take the average of these residuals across plants for a district.

As our data are repeated cross-sections, rather than panels with unique plant identifiers, there are limits with respect to some of our analyses. Perhaps most notably, we do not have accurate measures of exiting plants. Our data do, however, allow us to measure and study new entrants. Plants are distinguished by whether or not they are less than four years old. We will use the term "young" plant or new entrant to describe the activity of plants that are less than four years old. We aggregate young plant activity at the district level, similar to metrics of total activity.

Our core sample contains 312 districts. This sample is roughly half of the total number of districts in India of 630 , but it accounts for over $90 \%$ of plants, employment, and output in the manufacturing sector 
throughout the period of study. The reductions from the 630 baseline occur due to the following. First, the ASI surveys only record data for about 400 districts due to the lack of organized manufacturing (or its extremely limited presence) in many districts. ${ }^{8}$ Second, we drop states that have a small share of organized manufacturing. ${ }^{9}$ Last, we make an additional restriction for our regression sample that manufacturing activity in terms of plants, employment, and output in districts be observed at all points from 1994 to 2007.

The requirements with respect to continuous measurement of districts are motivated by a desire to have a consistent sample before and after the GQ upgrades. The requirements with respect to minimum share of states in organized manufacturing are motivated by a desire to have reasonably measured plant traits, especially with respect to labor productivity and plant TFP. With respect to the latter, we also exclude plants that have negative value added, which accounts for $6 \%-7 \%$ of employment. These restrictions are again not very significant in terms of economic activity, with our final sample retaining more than $90 \%$ of Indian manufacturing activity.

Our next step is to measure the distance of districts to various highway networks. We calculate these distances using official highway maps and ArcMap GIS software. Our reported results use the shortest straight-line distance of a district to a given highway network. We find very similar results when using the distance to a given highway network measured from the district centroid. The empirical appendix provides additional details on our data sources and preparation, with the most attention given to how we map GQ traits that we ascertain at the project level to district-level conditions for pairing with ASI data.

Our empirical specifications use a non-parametric approach with respect to distance to estimate treatment effects from the highway upgrades. We define indicator variables that take a value of one if the shortest distance of a district to the indicated highway network is within the specified range; a value of zero is assigned otherwise. We report most of our results using four distance bands: nodal districts, districts located 0-10 km from a highway, districts located 10-50 km from a highway, and districts over $50 \mathrm{~km}$ from a highway. In an alternative setup, the last distance band is further broken down into three bands:

\footnotetext{
${ }^{8}$ For instance, the ASI surveys the entire country except the states of Arunachal Pradesh, Mizoram, and Sikkim and Union Territory of Lakshadweep, so these states are naturally excluded.

${ }^{9}$ These states are Andaman and Nicobar Islands, Dadra and Nagar Haveli, Daman and Diu, Jammu and Kashmir, Tripura, Manipur, Meghalaya, Nagaland and Assam. The average share of organized manufacturing from these states varies from $0.2 \%$ to $0.5 \%$ in terms of establishment counts, employment or output levels.
} 
districts located 50-125 km from a highway, districts located 125-200 km from a highway, and districts over $200 \mathrm{~km}$ from a highway.

In all of our empirical work, our core focus is on the non-nodal districts of a highway. We measure effects for nodal districts, but the interpretation of these results will always be challenging as the highway projects are intended to improve the connectivity of the nodal districts. For the GQ network, we follow Datta (2011) in defining the nodal districts as Delhi, Mumbai, Chennai, and Kolkata. In addition, Datta (2011) describes several contiguous suburbs (Gurgaon, Faridabad, Ghaziabad, and NOIDA for Delhi; Thane for Mumbai) as being on the GQ network as "a matter of design rather than fortuitousness". We include these suburbs in the nodal districts. For the NS-EW network, we define Delhi, Chandigarh, NOIDA, Gurgaon, Faridabad, Ghaziabad, Hyderabad, and Bangalore to be the nodal districts using similar criteria as that applied to the GQ network.

Tables $1 \mathrm{a}$ and $1 \mathrm{~b}$ present simple descriptive statistics that portray some of the empirical results that follow. Table 1a starts by providing the count of districts by distance bands to the GQ network and by distance bands to the NS-EW network. As we do not need the panel nature of districts for these descriptive exercises, we retain some of the smaller districts that are not continuously measured to provide as complete a picture as possible (the total district count is 370). For both highway networks, roughly one-third of districts fall within $0-10$ or $10-50 \mathrm{~km}$ from the network, with roughly two-thirds of districts over $50 \mathrm{~km}$ away from the network.

Panel A provides descriptive tabulations from the 1994 and 2000 data that come before the GQ upgrades, and Panel B provides similar tabulations for the 2005 and 2007 data that follow the GQ upgrades. Columns 2-4 provide aggregates of manufacturing activity within each spatial grouping, averaging the two surveys, and Columns 5-7 provide similar figures for young establishments less than four years old. Column 8 provides means of labor productivity across plants in the range. One important observation from these tabulations is that non-nodal districts in close proximity to the highway networks typically account for around $40 \%$ of Indian manufacturing activity.

Table 1b provides some simple calculations. Panel A considers the log growth in activity from 1994/2000 to $2005 / 2007$, combining districts within spatial range. Panel B instead tabulates the change in the share of activity accounted for by that spatial band. Share changes in Panel B are calculated separately for distances from the GQ and NS-EW networks such that they sum to zero for each group. Accordingly, we do not present a totals row in Panel B. Share of labor productivity is also not a meaningful concept. 
Starting with the top row, our study is set during a period in which plant counts and output are growing for the organized sector, but employment levels are shrinking overall. This is true in general, and the divergence is even more pronounced for entrants. Accordingly, labor productivity for establishments is rising on average.

Looking at differences in growth patterns by distance from the GQ network, non-nodal districts within 10 $\mathrm{km}$ of the GQ network demonstrate growth that exceeds that in districts 10-50 km from GQ in every column. Moreover, in five of the seven columns, the growth in these very proximate districts also exceeds that in districts over $50 \mathrm{~km}$ away from the network. For convenience, we tabulate this ratio near the bottom of Panel A. The share changes in Panel B also tend to be quite strong considering the big increases in the nodal cities that are factored into these share changes.

Distance from the NS-EW highway system provides an interesting contrast, even at the level of these descriptive statistics. First, it is clear that we should be careful about assigning all of the changes observed for the GQ upgrades in nearby districts to the project, as districts near the NS-EW network also tend to exhibit growth differences compared to districts $50+\mathrm{km}$ away as a raw statistic despite the fact that the upgrade of NS-EW has only just begun by our sample end point. Second, districts near the GQ network appear to have especially increased plant counts and labor productivity compared to districts near the NSEW corridor. These patterns are not conclusive, perhaps most importantly because districts can be close to both highway systems as shown in Figure 1 (about 8\% of GQ is also part of NS-EW), but they provide a suggestive starting point for our work.

\section{Section 4: Empirical Analysis of the Impact of Highways on Economic Activity}

This section analyzes the impact of highway construction on manufacturing activity across districts. We use simple linear models with outcome variables expressed in logs, with the exception of TFP, which is expressed in unit standard deviations. Estimations include district and year fixed effects. These district fixed effects absorb long-run levels in manufacturing activity by district (along with any other fixed trait), while the year fixed effects absorb aggregate changes in the Indian manufacturing sector.

Estimations report standard errors clustered by district, weight observations by log total district population in 2001, and have 1,248 observations as the cross of four surveys and 312 districts. We winsorize outcome variables at the $1 \% / 99 \%$ level to guard against outliers. Our district sample is 
constructed such that employment, output, and establishment counts are continuously observed. We do not have this requirement for young plants, and we assign the minimum $1 \%$ value for employment, output, and establishment entry rates where zero entry is observed in order to model the extensive margin and maintain a consistent sample.

\section{Base Pre-Post Estimations of GQ Upgrades}

Table 2a shows the simplest panel estimations where explanatory variables in Panel A are interactions of two indicator variables for how far a district is from the GQ highway network with an indicator variable for the post-GQ upgrades (equal to one in 2005 and 2007). The district fixed effects control for the main effects of distance, and the year fixed effects control for the main effects of the post-GQ upgrades period. Thus, the interactions quantify differences in outcomes after the GQ upgrades by spatial band compared to the excluded group that comprises districts located more than $50 \mathrm{~km}$ from the GQ network.

Column headers provide the outcome variables studied. Columns 1-3 present measures of total activity in each district, Columns 4-6 present measures of new entry specifically, and Columns 7 and 8 present our average productivity measures. The first row shows increases in nodal district activity for Columns 1-6. As we have noted, we do not emphasize these results much given that the upgrades were built around the connectivity of the nodal cities. The imprecision in these estimates is mostly due to the fact that there are only nine nodal districts. As effects are being measured for each band relative to districts more than 50 $\mathrm{km}$ from the GQ network, the inclusion or exclusion of the nodal districts does not impact our core results regarding non-nodal districts.

Our primary emphasis is on the highlighted row where we consider districts that are 0-10 km from the GQ network but are not nodal districts. To some degree, the upgrades of the GQ network can be taken as exogenous for these districts. Columns 1-3 find limited effects for the total activity contained in these districts. As foreshadowed in Table 1b, we find positive point estimates for higher establishment counts and output in districts $0-10 \mathrm{~km}$ from the GQ network after the upgrades, but small declines in employment. These effects are not statistically significant, and this is not due to small sample size as we have 76 districts within this range. Columns 4-6 examine instead the entry margin by quantifying levels of young establishments and their activity. We find much sharper entry effects than the aggregate effects in Columns 1-3, and these entry results are precisely measured. The districts within 0-10 km of GQ have a 0.4-0.9 log point increase in entry activity after the GQ upgrade compared to districts more than $50 \mathrm{~km}$ away. We further discuss these differences between total levels and entry rates when reviewing Table $2 \mathrm{~b}$. 
Columns 7 and 8 show an increase in the average labor productivity and TFP in the districts $0-10 \mathrm{~km}$ from the GQ network. These increases are primarily driven by the incumbent establishments of the districts. We do not separately quantify the labor productivity and TFP changes of new entrants similar to Columns 4-6, as much of the impact of new entrants comes from the extensive margin and these plantlevel traits are not defined in these cases. The labor productivity result is also evident in a comparison of Columns 2 and 3, with the difference being that Column 7's measure is calculated at the plant level. We return to the interpretation of these productivity results after viewing the dynamic specifications.

For comparison, the third row of Panel A provides the interaction for the districts that are 10-50 km from the GQ network. None of the effects that we measure for the $0-10 \mathrm{~km}$ districts are observed at this spatial band, which provides a first assurance that these effects can be linked to the GQ upgrades rather than other features like regional growth differences.

Panel B extends the spatial horizons studies in Panel A to include two additional distance bands for districts 50-125 km and 125-200 km from the GQ network. These two bands have 48 and 51 districts, respectively. In this extended framework, we measure effects relative to the 97 districts that are more than $200 \mathrm{~km}$ from the GQ network in our sample. Three observations can be made. First, the results for districts $0-10 \mathrm{~km}$ are very similar when using the new baseline. Second, the null results generally found for districts 10-50 km from the GQ network mostly extend to districts 50-200 km from the GQ network. Even from a simple association perspective, the manufacturing growth in the period surrounding the GQ upgrades is localized in districts along the GQ network.

As a final and more speculative point, the negative point estimates in Columns 4-6 have a pattern that might suggest a "hollowing-out" of new entry towards districts more proximate to the GQ system after the upgrades. This pattern is similar to Chandra and Thompson's (2000) finding that U.S. counties that were next to counties through which U.S. highways were constructed were adversely affected. Chandra and Thompson (2000) described their results within a theoretical model of spatial competition whereby regional highway investments aid the nationally-oriented manufacturing industry and lead to the reallocation of economic activity in more regionally-oriented industries. The point estimates suggest a similar force might be occurring within Indian manufacturing as well, but the lack of statistical precision prevents strong conclusions in this regard. 
Returning to the differences between Columns 1-3 and 4-6, we suspect that three factors are behind the weaker response on total activity compared to entry. First, our post-upgrades data come from 2005 and 2007, which is just at the end of the GQ upgrades that began in 2001. It takes time for activity to shift spatially, especially if there are agglomeration forces or similar with existing industry bases, and we are likely under-estimating the ultimate changes that may occur in the spatial distribution of Indian manufacturing as a consequence. By contrast, the entry margin - where location choices are being made at present - adjust much faster to the changing attractiveness of regions, and thus register sharper effects in the short- to medium-run. A second reason why total shifts in activity may be dampened in districts on the GQ network is that entrants may be displacing incumbent establishments from the districts. In fact, this competition is a key reason cited by proponents for infrastructure investments. Unfortunately, our data do not allow us to study the exit margin with sufficient detail to make accurate assessments.

Table $2 \mathrm{~b}$ presents evidence on a third rationale that partly overlaps with the other two. Prior to the GQ project, there existed some infrastructure linking these cities. In a minority of cases, the existing roads did not even comprise the beginning of a highway network, and so the GQ project built highways where none existed before. In other cases, however, a basic highway existed that could be upgraded. Of the 70 districts lying near the GQ network, new highway stretches comprised some or all of the construction for 33 districts, while 37 districts experienced purely upgrade work.

In Table $2 \mathrm{~b}$, we split the $0-10 \mathrm{~km}$ interaction variable for these two types of interventions. The results are very interesting. Columns 4-8 show mostly similar entry and productivity consequences regardless of the initial roadwork's condition. Columns 1-3, however, show distinct effects regarding total activity. Places that completely lacked a highway before GQ exhibit increases in aggregate activity. In these cases, the entry has enough aggregate consequences to register during the time period of our study. On the other hand, upgrades of existing facilities display null effects. Because of the earlier two limitations noted, it could be that upgraded portions will also demonstrate increases in aggregate activity in the long-run.

\section{Dynamic Specifications}

Table 3a presents a dynamic version of the pre-post estimations using the shorter spatial horizon that measures effects relative to districts $50+\mathrm{km}$ from the GQ network. In this specification, we interact the indicator variables for district distance bands with indicator variables for the years 2000, 2005, and 2007. By separately estimating effects for each year, we can observe whether the growth patterns appear to 
follow the GQ upgrades hypothesized to cause them. Effects are measured relative to the 1994 period. We include but do not report interactions for nodal districts and each year, as well.

The patterns in Columns 4-6 are comforting for the entry results. We do not observe a substantial uptick in 2000 that would suggest a pre-trend to the GQ upgrades. This lack of pre-trend also extends to the total activity measures in Columns 1-3, although we did not observe a substantial pre-post effect for these results anyway with the full sample. Likewise, we do not observe any worrisome patterns for the districts 10-50 km apart from the GQ network. In fact, the latter provide additional support in that the coefficients for the 2000 interaction in the $0-10 \mathrm{~km}$ (top row) are similar to those for $10-50 \mathrm{~km}$ (fourth row), while the subsequent differences in entry rates in 2005 and 2007 are quite stark.

By contrast, the dynamic specifications suggest that some caution is warranted in interpreting the observed growth in labor productivity and TFP for districts 0-10 km from the GQ network. The first row in Columns 7 and 8 show non-trivial performance declines in 2000 compared to 1994 for these districts; they also highlight that much of the performance gain we observe in Table 2a is through a comparison of outcomes in 2005 and 2007 against outcomes in 2000, rather than compared to 1994.

There are two potential interpretations that could follow. The first, less-positive interpretation is that the performance gain we observe in Table $2 \mathrm{a}$ is a recovery from some short-term decline in productivity that is spuriously timed with the GQ upgrades. Some evidence in support of this story is registered in the fact that TFP growth reverts back to almost 1994 levels in Column 8. However, a second, more-positive interpretation is that the GQ upgrades managed to stop and reverse some adverse decline in productivity that these districts were experiencing. Some evidence in support of this story is evident in the fact that districts $10-50 \mathrm{~km}$ from the GQ network also experienced lower productivity in 2000 that did not subsequently recover. In the end, our analysis provides equal support to both interpretations.

In summary, the dynamic specifications of Table 3a provide support for a causal link in that the observed increases in entry rates from the simple pre-post estimations have a timing that appears well aligned with the GQ upgrades. On the other hand, the productivity results are more difficult to interpret and may suggest that our productivity findings in Table $2 \mathrm{a}$ are upwardly biased due to a rebound effect from spuriously lower productivity levels in 2000.

Table $3 b$ takes a second dynamic approach. Due to the size of the GQ project, some sections were completed earlier than other sections. Using our framework from Table 2a, we further interact our 
indicator variable for being $0-10 \mathrm{~km}$ from the GQ network with indicator variables for whether the district's work was completed by March 2003, March 2006, or later. Of the 70 districts, 27 districts were completed prior to March 2003, 27 districts between March 2003 and March 2006, and 16 districts afterwards. In almost every case in Table $3 b$, the relative sizes of the effects by implementation date are consistent with the project's completion taking hold and influencing economic activity. Given that our final data survey comes from 2007, it is not surprising that we do not yet see substantial activity in the districts completed after March 2006. On the other hand, expansions in activity are generally strongest for districts that were completed by March 2003. Again, the timing of the GQ upgrades is consistent with the results we observe.

\section{Comparison of GQ Upgrades to NS-EW Highway}

Table 4 compares districts proximate to the GQ network to districts proximate to the NS-EW highway network that was not upgraded. The idea behind this comparison is that districts that are at some distance from the GQ network may not be a good control group if they have patterns of evolution that do not mirror what districts immediately on the GQ system would have experienced had the GQ upgrades not occurred. This comparison to the NS-EW corridor provides perhaps a stronger foundation in this regard, especially as its upgrades were planned to start close to those of the GQ network before being delayed.

The upgrades scheduled for the NS-EW project were to start contemporaneous to and after the GQ project. To ensure that we are comparing apples to apples, we identified the segments of the NS-EW project that were to begin with GQ and those that were to follow in the next phase. We use separate indicator variables for these two groups so that we can compare against both. Of the 76 districts lying with 0-10 km of NS-EW, 40 districts were to be covered in the 48 NS-EW projects identified for Phase I. The empirical appendix provides greater detail on this division.

The powerful result from Table 4 is that none of the outcomes we measure for the GQ system in the postupgrade period are observed for districts along the NS-EW corridor. The placebo-like coefficients from the interactions of post-GQ upgrades with districts lying between 0-10 km from the NS-EW highway are mostly negative and never statistically significant. The lack of precision is not due to too few districts along the NS-EW system, as the district counts are comparable and the standard errors are of very similar magnitude. In Appendix Table 1, we show that null results continue to hold when we combine the NSEW indicator variables and that the coefficients are well estimated. Said differently, with the precision that we estimate the positive responses along the GQ network, we estimate a lack of a change along the 
NS-EW corridor. Along with the dynamic results in Tables $3 \mathrm{a}$ and $3 \mathrm{~b}$, these patterns speak to the likely link of the economic changes to the GQ upgrades.

\section{Industry Heterogeneity in Entry Patterns}

Our last two analyses change the focus from estimating aggregate effects from the GQ upgrades to identifying in greater detail the heterogeneity in the effects observed by important industry or district traits. These exercises provide additional confidence around the patterns developed and, as highlighted below, have special policy relevance in India.

Table 5 describes a key feature of the industry heterogeneity in entry that occurred after the GQ upgrades. We focus specifically on the land and building intensity of industries. We select this intensity due to the intuitive inter-relationship that non-nodal districts may have with nodal cities along the GQ network due to the general greater availability of land outside of urban centers and its cheaper prices. This general urban-rural or core-periphery pattern is evident in many countries and is associated with efficient sorting of industry placement. Moreover, this feature has particular importance in India due to government control over land and building rights, leading some observers to state that India has transitioned from its “license Raj" to a "rents Raj" (e.g., Subramanian, 2012a,b). Given India's distorted land markets, the heightened connectivity brought about by the GQ upgrades may be particularly important for efficient sorting of industry across spatial locations.

We measure land and building intensity at the national level in the year 2000 through the industry's closing net value of the land and building per unit of output. Appendix Table 2 provides specific values, and we find similar results when only using land intensity. In Table 5, we repeat our entry specifications isolating district activity observed for industries in three bins: those with low land intensity (the bottom quartile of intensity), medium intensity (the middle two quartiles), and high intensity (the top quartile).

The patterns in Table 5 are striking. The districts $0-10 \mathrm{~km}$ from the GQ network show a pronounced growth in entry by industries that are land and building intensive. With all three outcome measures of establishments, employment, and output, there are no adjustments in entry for the least-intensive industries. This entry effect only becomes statistically and economically important at moderate land and building intensities, and the effect is largest for industries with the highest intensities. As remarkable, the opposite pattern is generally observed in the top row for nodal districts-where nodal districts are 
experiencing heightened entry of industries that are less land and building intensive after the GQ upgrades - and no consistent patterns are observed for districts 10-50 km from the GQ network.

These patterns suggest that the GQ upgrades may have helped with the efficient sorting of industries across locations. Ghani et al. (2012) find that infrastructure aids efficient sorting of industries and plants within districts, and these patterns show a greater efficiency across districts. Many studies have warned about the misallocation in the Indian economy (e.g., Hsieh and Klenow 2009), and these results suggest better connectivity across districts may be able to reduce some of these distortions. More speculatively, these results also suggest that infrastructure may improve upon land market distortions caused by the "rent Raj" and similar. ${ }^{10}$

\section{Highways and Spatial De-Concentration}

The development and growth of Indian economy in the last two decades has been accompanied by widening spatial disparities. Cities like Gurgaon in Haryana and Bangalore in Karnataka have experienced high growth in economic activity and real estate developments, while many other places remain mired in poverty and stagnation. These differentials are common to many developing economies (e.g., World Development Report 2009), as well as advanced economies. For instance, China's growth is attributable mainly to coastal provinces. However, unlike China, growth in India's moderate-sized cities is relatively lower. ${ }^{11}$ Desmet et al. (2012) argue that manufacturing in India is slowly moving away from high-density districts to districts that are less congested, allowing industrial activity to spread more equally across space.

In this section, we examine whether investment in infrastructure such as highways can play a role in facilitating the shift of manufacturing activity to intermediate-sized districts. We group districts into three bins based on their population density: low-density districts are below the median density for India (up to 353 persons per square $\mathrm{km}$ ); moderate-density districts are those in the middle two quartiles (353-693

\footnotetext{
${ }^{10}$ We also find evidence of heightened entry following GQ upgrades within industries in the top quartile of the skill distribution in nodal districts and in districts $0-10 \mathrm{~km}$ from the GQ network. Unlike land-intensity, this entry is uniform and does not display a sorting pattern.

${ }^{11}$ McKinsey Global Institute (2012) highlights the increasing prominence of intermediate cities in many economies, predicting they will account for half of future GDP growth. McKinsey Global Institute (2010) argues there are between 70 and 100 medium-sized specialist cities in India whose economies focus on an anchor sector like manufacturing, resources, transportation, or tourism.
} 
persons per square $\mathrm{km}$ ), and high-density districts are those in the top quartile (over 693 persons per square $\mathrm{km})$.

Table 6 presents the results of interacting the three regressors from our typical approach with indicator variables for the various density bins. The one exception is that all of the nodal districts are above the median density for India, and so we do not have a low-density nodal-district effect. Effects continue to be measured against districts farther than $50 \mathrm{~km}$ from the GQ network.

The results in Table 6 suggest that the GQ upgrades have increased new entry the most in high- and medium-density districts that lie 0-10 km from the GQ network. For instance, moderate-density districts, like Surat in Gujarat or Srikakulam in Andhra Pradesh, that lie on the GQ highway registered more than $100 \%$ increase in new output and new establishment counts after GQ upgrades. On the other hand, the GQ upgrades are not linked to heightened entry or performance in low-density areas. One interpretation of these results is that the improved connectivity enables manufacturing establishments to efficiently locate in intermediate cities, but that localization economies prevalent for the sector continue to preclude entry in low-density places. ${ }^{12}$

Our findings are similar to Baum-Snow et al. (2012) who identify how infrastructure aided the decentralization of industrial production and population in Chinese cities from 1990-2010. Henderson et al. (2001) similarly find that industrial decentralization in Korea is attributable to massive transport and communications infrastructure investments in the early 1980s. These and similar studies form the foundation for development recommendations with respect to infrastructure found in the World Bank's (2012) Urbanization Review Flagship Report and comparable policy reports. ${ }^{13}$

\section{Section 5: Conclusions}

This paper evaluates the impact of a large-scale highway project on economic activity in the Indian manufacturing sector using establishment-level survey data from 1994-2007. The Golden Quadrilateral highway project of India upgraded the quality and width of 5,846 km of highways linking four major hubs in India. In the process, this upgrade improved the connectivity and market accessibility of districts lying close to the highway compared to those more removed. Non-nodal districts located within $0-10 \mathrm{~km}$

\footnotetext{
${ }^{12}$ For example, Duranton and Puga (2001, 2004), Rosenthal and Strange (2004), Ellison et al. (2010), and Gill and Goh (2010).

${ }^{13}$ Henderson (2010) provides a broader review of the role of cities in development.
} 
from the GQ network experienced substantial increases in entry levels and higher productivity. Dynamic specifications and comparisons to the NS-EW highway system mostly confirm these conclusions, with the most substantial caveat being that the productivity gains may be upwardly biased by a pre-period dip. The GQ upgrades also appear to have facilitated a more natural sorting of industries that are land and building intensive from the nodal districts into the periphery locations; the upgrades also appear to be encouraging decentralization by making intermediate cities more attractive for manufacturing entrants.

There are several points of future research that we hope to undertake. First, we are continuing to examine the extent to which the GQ project improved the allocative efficiency of the manufacturing sector in India. Given the high levels of misallocation with which India is starting, improvements in allocation are most important. Second, we intend to study next the impact of the GQ upgrades on the unorganized sector. Ghani et al. (2012) highlight the extent to which the organized and unorganized sectors are moving in different directions within India, with the unorganized sector becoming more urbanized, and we need to better understand the role that infrastructure connections across districts play in this process. This work will also examine issues like the gender of business owners to understand how improved highways affect sub-groups of the population differently. Finally, looking beyond the manufacturing sector, it will be very interesting to use satellite-based data to examine the aggregate economic outcome associated with these upgrades. 


\section{References}

Ahluwalia, M. (2000). "Economic Performance of States in the Post Reforms Period". Economic and Political Weekly, 35(19):1637-1648

Aschauer, D.A. (1989). “Is Public Expenditure Productive?". Journal of Monetary Economics, 23(2): 177-200.

Banerjee, A., E. Duflo and N. Qian. (2012). "On the Road: Access to Transportation Infrastructure and Economic. Growth in China”. NBER Working Paper No. 17897.

Baum-Snow, N. (2007). "Did Highways Cause Suburbanization?". Quarterly Journal of Economics 122(2): 775-805.

Baum-Snow, N., L. Brandt, V. Henderson, M. Turner and Q. Zhang. (2012). "Roads, Railroads and Decentralization of Chinese Cities". Working Paper.

Besley, T. and R. Burgess. (2004). "Can Labor Regulation Hinder Economic Performance? Evidence from India?”. The Quarterly Journal of Economics, 119(1): 91-134.

Brown, D., M. Fay, J. Felkner, S. Lall and H. Wang. (2008). "The Death of Distance? Economic Implications of Infrastructure Improvement in Russia". EIB Papers, 13(2): 126-147.

Chandra, A. and E. Thompson, E. (2000). "Does Public Infrastructure Affect Economic Activity? Evidence from the Rural Interstate Highway System". Regional Science and Urban Economics, 30(4): 457-490.

Datta, S. (2011). “The Impact of Improved Highways on Indian Firms". Journal of Development Economics, 99(1): 46-57.

Desmet, K., E. Ghani, S. O'Connell, and E. Rossi-Hansberg (2012), “The Spatial Development of India”. World Bank Policy Research Paper 6060.

Dinkelman, T. (2011). "The Effects of Rural Electrification on Employment: New Evidence from South Africa". American Economic Review, 101(7): 3078-3108.

Donaldson, D. (2010). "Railroads and the Raj: The Economic Impact of Transportation Infrastructure". NBER Working Paper No. 16487.

Donaldson, D. and R. Hornbeck. (2012). "Railroads and American Economic Growth: New Data and Theory". Working Paper.

Duflo, E. and R. Pande. (2007). “Dams”. Quarterly Journal of Economics, 122 (2): 601-646.

Duranton, G. and D. Puga. (2004) "Micro-Foundations of Urban Agglomeration Economies". In Vernon Henderson and Jacques François Thisse (eds.) Handbook of Regional and Urban Economics, Volume 4 (Amsterdam: North-Holland): 2063-2117.

Duranton, G. and D. Puga (2001). "Nursery Cities: Urban Diversity, Process Innovation, and the Life Cycle of Products". American Economic Review, 91(5): 1454-1477.

Duranton, G. and M. Turner. (2011). "The Fundamental Law of Road Congestion: Evidence from US Cities". American Economic Review, 101(6): 2616-2652. 
Duranton, G. and M. Turner. (2012). “Urban Growth and Transportation”. Review of Economic Studies, forthcoming.

Ellison, G., E. Glaeser and W. Kerr. (2010). "What Causes Industry Agglomeration? Evidence from Coagglomeration Patterns", American Economic Review 100(3): 1195-1213.

Fernald, J.G. (1998). "Roads to Prosperity? Assessing the Link between Public Capital and Productivity". The American Economic Review, 89(3): 619-638.

Fernandes, A. and A. Pakes. (2008). "Factor Utilization in Indian Manufacturing: A Look at the World Bank Investment Climate Survey Data”. NBER Working Paper No. 14178.

Ghani, E., W. Kerr, and S. O'Connell. (2011). "Spatial Determinants of Entrepreneurship in India". NBER Working Paper No. 17514.

Ghani, E., A. Goswami, and W. Kerr. (2012). "Is India's Manufacturing Sector Moving Away from Cities?”. NBER Working Paper No. 17992.

Gill Indermit and Chor-Ching Goh. (2012). "Scale Economies and Cities". World Bank Research Observer, 25(2): 235-262.

Gupta, P., R. Hasan, and U. Kumar. (2008). “What Constrains Indian Manufacturing?”. ICRIER Working Paper No. 211.

Gupta, P. and U. Kumar. (2010). "Performance of Indian Manufacturing in the Post Reform Period". Working Paper.

Hasan, R. and K. Jandoc. (2010). "The Distribution of Firm Size in India: What Can Survey Data Tell Us?”. ADB Economics Working Paper No. 213.

Henderson, V. (2010). “Cities and Development”. Journal of Regional Science, 50(1): 515-540.

Holl, A. and E. Viladecans-Marsal. (2011). "Infrastructure and Cities: The Impact of New Highways on Urban Growth”. Universitat de Barcelona-Institut d'Economia de Barcelona Working Paper.

Hsieh, C. and P. Klenow. (2009). "Misallocation and Manufacturing TFP in China and India". The Quarterly Journal of Economics, 124(4): 1403-1448.

Hsu, W-T and H. Zhang. (2011). "The Fundamental Law of Highway Congestion: Evidence from Japanese Expressways". Chinese University of Hong Kong Working Paper.

Kathuria, V., S. Natarajan, R. Raj, and K. Sen. (2010). "Organized versus Unorganized Manufacturing Performance in India in the Post-Reform Period". MPRA Working Paper No. 20317.

Kochhar, K. U. Kumar, R. Rajan, A. Subramanian and I. Tokatlidis. (2006). "India's Pattern of Development: What Happened, What Follows?”. IMF Working Paper No. 06/22.

Lahr, M., R. Duran and A. Varughese. (2005). "Estimating the Impact of Highways on Average Travel Velocities and Market Size”. Unpublished mimeo.

McKinsey Global Institute. (2010). "India's Urban Awakening: Building Inclusive Cities, Sustaining Economic Growth". McKinsey \& Company, April 2010.

McKinsey Global Institute. (2012). "The Shifting Urban Economic Landscape: What Does it Mean for Cities?”. McKinsey \& Company, July 2012. 
Michaels, G. (2008). "The Effect of Trade on the Demand for Skill: Evidence from the Interstate Highway System". The Review of Economics and Statistics, 90 (4): 683-701.

Mitra, A., A. Varoudakis and M. Véganzonès. (1998). "State Infrastructure and Productive Performance in Indian Manufacturing”. OECD Working Paper No. 139

Munell, A. (1990). "Why has Productivity Growth Declined? Productivity and Public Investment". New England Economic Review, January/February: 3-22.

Nataraj, S. (2011). "The Impact of Trade Liberalization on Productivity: Evidence from India's Formal and Informal Manufacturing Sectors”. Journal of International Economics, 85(2): 292-301.

Otto, G. and G. Voss. (1994). "Public Capital and Private Sector Productivity". The Economic Record, 70(209): 121-132.

Roberts, M., U. Deichmann, B. Fingleton and T. Shi. (2012). "Evaluating China's Road to Prosperity: A New Economic Geography Approach”. Regional Science and Urban Economics, 42(4): 580-594.

Rosenthal, S. and W. Strange. (2004). "Evidence on the Nature and Sources of Agglomeration Economies". In Vernon Henderson and Jacques François Thisse (eds.) Handbook of Regional and Urban Economics, Volume 4 (Amsterdam: North-Holland): 2119-2171.

Subramanian, Arvind. (2012a). “The Ideas India Must Shed”. June 4th, 2012.

Subramanian, Arvind. (2012b). "What is India's Real Growth Potential”. May 23, 2012.

The Economic Times. (2012). "Highway Development Requires Rs 200 cr Investment Every Day". April $29,2012$.

The World Bank. (2012). "Planning, Connecting, and Financing Cities-Now". Urbanization Review Flagship Report, The World Bank, Washington DC.

Ulimwengu, J., J. Funes, D. Headey and L. You. (2009). "Paving the Way for Development? The Impact of Transport Infrastructure on Agricultural Production and Poverty Reduction in the Democratic Republic of Congo". IFPRI Discussion Paper No. 00944.

World Development Report. (2009). Reshaping Economic Geography, The World Bank, Washington DC.

World Road Statistics. (2009). World Road Statistics 2009: Data 2002-2007. International Road Federation, Geneva. 


\section{Empirical Appendix}

This appendix describes some key resources and data preparation steps regarding highway segments.

Data Source on GQ Details: As per the National Highway Authority of India (NHAI), the GQ highway venture was a collection of 128 projects implemented all over the country. By March 2011, 120 of these projects had been completed, while eight were either pending completion or terminated. We compiled information on each of these 120 projects from the annual reports of NHAI from 1998-99 to 2010-2011 as well as from the Ministry of Roads, Transport and Highways. These annual reports identified the project name for the highway stretch, the length of the highway stretch, the national highway number, the start date for the project, and target and actual completion dates.

Mapping GQ Projects to Districts: In most cases, the name of the project indicated the start and end towns on a highway stretch. This information was used to identify districts lying within $10 \mathrm{~km}$ of the highway stretch. The start and end points of the segment along the highway were located in the shape file and that segment was then selected to query all of the districts located within $10 \mathrm{~km}$ of that segment in the GIS software. In some cases, the project name was not clear or the town name could not be located using the shape file, Google maps, or open street maps. In such cases, we used information on the NHAI website for the highway project chainage and mapped the preceding or succeeding highway stretch. We then traced back kilometer by kilometer on the specified highway number to get the names of the towns that would lie close to the highway stretch.

New Construction versus Upgrades: We obtained information on whether each GQ project focused on new highway construction or the renovation and upgrade of an existing highway using a supplier database called Process Register. Process Register is a comprehensive online reference database of suppliers of products and services used in the process, energy, and greater manufacturing industries. NHAI is a listed supplier on Process Register and most NHAI projects are listed in the database. Of the 70 districts lying near the GQ network, 37 districts experienced purely upgrade work. For 33 districts, some or all of the work was new construction.

Implementation Date: We grouped projects by whether they were completed by March 2003, March 2006, or later. We then matched districts to individual highway projects and their completion dates. Several districts touch two or more stretches of highway. For such districts, we allocated them to the earliest completion date as they had access to some connectivity before other districts did. However, we did not allocate a district into an earlier bin if the earlier GQ project was River Over Bridge (ROB), a bridge section, or a short bypass, as most of these constructions were small in terms of kilometers of length.

There were some highway projects, such as Vijayawada-Chilkaluripet, which came in several packages, and we could not distinguish among packages in terms of identifying districts because the start and end points were the same in all packages. Fortunately, in most cases, such projects were implemented in the same time period, so we could combine projects to get the set of districts lying within $10 \mathrm{~km}$ of the project in question.

Of the 70 districts, 27 districts were completed prior to March 2003, 27 districts between March 2003 and March 2006, and 16 districts after March 2006. Two districts (Pali, Nadia) cannot be classified through the standard route and required research to ascertain. Pali was classified as being after March 2006 and new construction; Nadia was classified as being after March 2006 and upgrade. Additional details about these decisions are available from the authors.

NS-EW Highway Phase I: NS-EW highway projects were identified from the annual reports noted above. The reports do not explicitly identify projects on the NS-EW corridor as being Phase I or Phase II. Thus, a project was assigned to be part of Phase I if the target completion date was prior to December 2004, that is, a year after the approval of the NHDP Phase II when a full-fledged NS-EW upgrade plan was approved by the Cabinet Committee on Economic Affairs. NS-EW corridor projects under NHDP Phase II did not start until January 2005. In total, 48 NS-EW projects were identified that aggregate approximately $981 \mathrm{~km}$ of NS-EW planned to be completed in Phase I of NHDP. Of the 48 projects, 15 were to be implemented on the East-West corridor while the rest were scheduled for the North-South highway. Of the 76 districts lying with 0-10 km of the NS-EW system, 40 districts were to be covered in the 48 NS-EW projects identified for Phase I. 


\section{Figure 1: Highway networks in India}

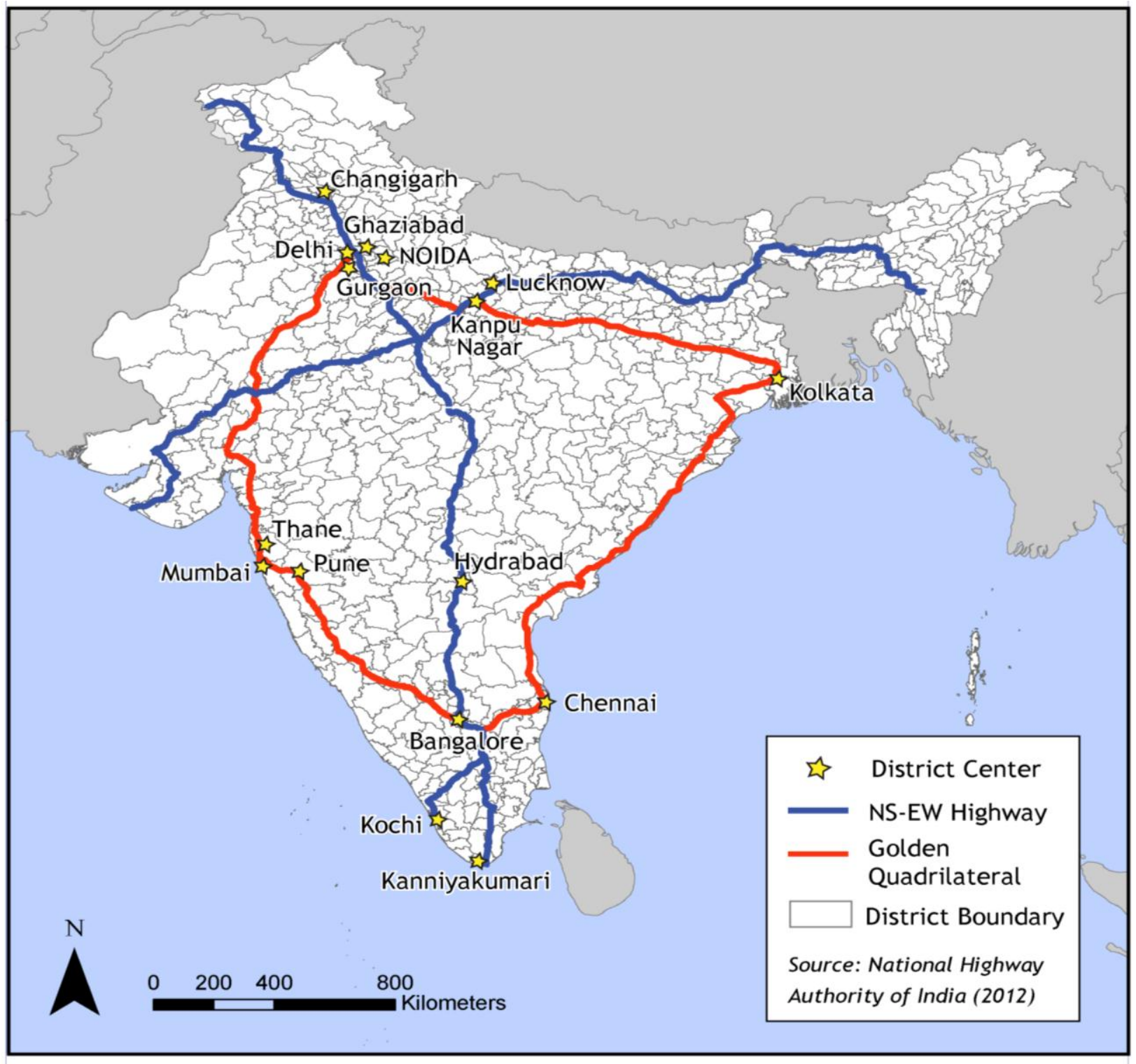


Table 1a: Descriptive statistics

\begin{tabular}{|c|c|c|c|c|c|c|c|c|}
\hline & \multirow{2}{*}{$\begin{array}{c}\text { Count of } \\
\text { districts }\end{array}$} & \multicolumn{3}{|c|}{ Levels of total activity } & \multicolumn{3}{|c|}{ Levels of young firm activity } & \multirow{2}{*}{$\begin{array}{c}\text { Labor } \\
\text { productivity }\end{array}$} \\
\hline & & Plants & Employment & Output & Plants & Employment & Output & \\
\hline & $(1)$ & $(2)$ & $(3)$ & $(4)$ & $(5)$ & $(6)$ & $(7)$ & $(8)$ \\
\hline & \multicolumn{8}{|c|}{ A. Average levels of activity in 1994 and 2000, combining districts within spatial range } \\
\hline Total & 370 & 81,641 & $5,879,283$ & $3.9 \mathrm{E}+11$ & 12,166 & 563,479 & $4.5 \mathrm{E}+10$ & 66,998 \\
\hline Nodal district for GQ & 9 & 11,365 & 723,042 & $5.8 \mathrm{E}+10$ & 1,403 & 71,037 & $5.2 \mathrm{E}+09$ & 80,312 \\
\hline District $0-10 \mathrm{~km}$ from GQ & 76 & 24,816 & $2,098,769$ & $1.3 \mathrm{E}+11$ & 4,054 & 196,958 & $1.5 \mathrm{E}+10$ & 62,998 \\
\hline District $10-50 \mathrm{~km}$ from GQ & 42 & 6,003 & 375,423 & $3.4 \mathrm{E}+10$ & 1,069 & 44,087 & $5.8 \mathrm{E}+09$ & 90,506 \\
\hline District over $50 \mathrm{~km}$ from GQ & 243 & 39,456 & $2,682,049$ & $1.7 \mathrm{E}+11$ & 5,641 & 251,398 & $1.9 \mathrm{E}+10$ & 63,248 \\
\hline Nodal district for NS-EW & 11 & 8,283 & 515,053 & $3.5 \mathrm{E}+10$ & 1,250 & 61,913 & $3.6 \mathrm{E}+09$ & 68,714 \\
\hline District 0-10 km from NS-EW & 90 & 21,036 & $1,291,904$ & $7.9 \mathrm{E}+10$ & 2,913 & 122,358 & $8.9 \mathrm{E}+09$ & 61,165 \\
\hline District $10-50 \mathrm{~km}$ from NS-EW & 68 & 10,484 & 727,345 & $4.7 \mathrm{E}+10$ & 1,711 & 80,605 & $5.6 \mathrm{E}+09$ & 64,349 \\
\hline \multirow[t]{2}{*}{ District over $50 \mathrm{~km}$ from NS-EW } & 201 & 41,838 & $3,344,982$ & $2.3 \mathrm{E}+11$ & 6,292 & 298,602 & $2.7 \mathrm{E}+10$ & 69,563 \\
\hline & \multicolumn{8}{|c|}{ B. Average levels of activity in 2005 and 2007, combining districts within spatial range } \\
\hline Total & 370 & 100,951 & $3,571,552$ & $1.1 \mathrm{E}+12$ & 16,104 & 390,145 & $1.2 \mathrm{E}+11$ & 300,003 \\
\hline Nodal district for GQ & 9 & 13,751 & 489,068 & $1.7 \mathrm{E}+11$ & 2,317 & 68,171 & $1.8 \mathrm{E}+10$ & 341,215 \\
\hline District $0-10 \mathrm{~km}$ from GQ & 76 & 33,774 & $1,208,338$ & $4.0 \mathrm{E}+11$ & 5,681 & 135,277 & $3.9 \mathrm{E}+10$ & 330,839 \\
\hline District $10-50 \mathrm{~km}$ from GQ & 42 & 7,410 & 222,213 & $8.4 \mathrm{E}+10$ & 1,228 & 21,779 & $5.9 \mathrm{E}+09$ & 376,240 \\
\hline District over $50 \mathrm{~km}$ from GQ & 243 & 46,017 & $1,651,932$ & $4.2 \mathrm{E}+11$ & 6,878 & 164,918 & $5.7 \mathrm{E}+10$ & 254,992 \\
\hline Nodal district for NS-EW & 11 & 11,790 & 459,878 & $1.2 \mathrm{E}+11$ & 2,178 & 76,201 & $1.4 \mathrm{E}+10$ & 266,600 \\
\hline District 0-10 km from NS-EW & 90 & 24,194 & 913,526 & $2.2 \mathrm{E}+11$ & 3,409 & 86,212 & $2.5 \mathrm{E}+10$ & 241,124 \\
\hline District $10-50 \mathrm{~km}$ from NS-EW & 68 & 12,149 & 363,300 & $8.4 \mathrm{E}+10$ & 1,771 & 28,999 & $8.7 \mathrm{E}+09$ & 230,459 \\
\hline District over $50 \mathrm{~km}$ from NS-EW & 201 & 52,818 & $1,834,848$ & $6.4 \mathrm{E}+11$ & 8,746 & 198,734 & $7.2 \mathrm{E}+10$ & 351,460 \\
\hline
\end{tabular}

Notes: Descriptive statistics calculated from Annual Survey of Industries. Districts are local administrative units that generally form the tier of local government immediately below that of India's subnational states and territories. These are the smallest entities for which data is available with ASI. Nodal districts include Delhi, Mumbai, Kolkata, and Chennai and their contiguous suburbs (Gurgaon, Faridabad, Ghaziabad, and NOIDA for Delhi; Thane for Mumbai). The indicator variable for District 0-10 km from GQ takes a unit value for non-nodal districts that have minimum straight-line distance from the GQ network of less than $10 \mathrm{~km}$; other distance-related indicator variables are defined analogously. For the NS-EW network, we define Delhi, Chandigarh, NOIDA, Gurgaon, Faridabad, Ghaziabad, Hyderabad, and Bangalore to be the nodal districts. Labor productivity is total output per employee. 
Table 1b: Descriptive statistics, continued

\begin{tabular}{|c|c|c|c|c|c|c|c|}
\hline & \multicolumn{3}{|c|}{ Levels of total activity } & \multicolumn{3}{|c|}{ Levels of young firm activity } & \multirow{2}{*}{$\begin{array}{l}\text { Log labor } \\
\text { productivity }\end{array}$} \\
\hline & Plants & Employment & Output & Plants & Employment & Output & \\
\hline & $(1)$ & $(2)$ & (3) & (4) & $(5)$ & $(6)$ & $(7)$ \\
\hline Total & 1.019 & 0.968 & 1.037 & 1.030 & 0.972 & 1.040 & 1.135 \\
\hline Nodal district for GQ & 1.020 & 0.971 & 1.043 & 1.069 & 0.996 & 1.056 & 1.128 \\
\hline District over $50 \mathrm{~km}$ from GQ & 1.015 & 0.967 & 1.035 & 1.023 & 0.966 & 1.046 & 1.126 \\
\hline Nodal district for NS-EW & 1.039 & 0.991 & 1.051 & 1.078 & 1.019 & 1.061 & 1.122 \\
\hline District 0-10 km from NS-EW & 1.014 & 0.975 & 1.041 & 1.020 & 0.970 & 1.046 & 1.124 \\
\hline District $10-50 \mathrm{~km}$ from NS-EW & 1.016 & 0.949 & 1.024 & 1.005 & 0.910 & 1.020 & 1.115 \\
\hline District over $50 \mathrm{~km}$ from NS-EW & 1.022 & 0.960 & 1.039 & 1.038 & 0.968 & 1.041 & 1.145 \\
\hline Ratio of $0-10$ GQ to $0-10$ NS-EW groups & \multicolumn{7}{|c|}{ B. Change in share of activity from $1994 / 2000$ to $2005 / 2007$, combining districts within spatial range } \\
\hline Nodal district for GQ & -0.003 & 0.014 & 0.008 & 0.029 & 0.049 & 0.036 & n.a. \\
\hline District 0-10 km from GQ & 0.031 & -0.019 & 0.037 & 0.020 & -0.003 & -0.006 & n.a. \\
\hline District $10-50 \mathrm{~km}$ from GQ & 0.000 & -0.002 & -0.008 & -0.012 & -0.022 & -0.080 & n.a. \\
\hline District over $50 \mathrm{~km}$ from GQ & -0.027 & 0.006 & -0.038 & -0.037 & -0.023 & 0.050 & n.a. \\
\hline Nodal district for NS-EW & 0.015 & 0.041 & 0.025 & 0.032 & 0.085 & 0.034 & n.a. \\
\hline District 0-10 km from NS-EW & -0.018 & 0.036 & 0.005 & -0.028 & 0.004 & 0.015 & n.a. \\
\hline District $10-50 \mathrm{~km}$ from NS-EW & -0.008 & -0.022 & -0.041 & -0.031 & -0.069 & -0.051 & n.a. \\
\hline District over $50 \mathrm{~km}$ from NS-EW & 0.011 & -0.055 & 0.011 & 0.026 & -0.021 & 0.002 & n.a. \\
\hline
\end{tabular}

Notes: See Table 1a. Share changes in Panel B are calculated separately for distances from the GQ and NS-EW networks such that they sum to zero for each group. 
Table 2a: Pre-post estimations of the impact of GQ improvements on manufacturing activity

\begin{tabular}{|c|c|c|c|c|c|c|c|c|}
\hline & \multicolumn{3}{|c|}{ Log levels of total activity } & \multicolumn{3}{|c|}{ Log levels of young firm activity } & \multirow{2}{*}{$\begin{array}{l}\text { Log labor } \\
\text { productivity }\end{array}$} & \multirow{2}{*}{$\begin{array}{l}\text { Total factor } \\
\text { productivity }\end{array}$} \\
\hline & Plants & Employment & Output & Plants & Employment & Output & & \\
\hline & $(1)$ & $(2)$ & (3) & (4) & $(5)$ & $(6)$ & $(7)$ & $(8)$ \\
\hline & \multicolumn{8}{|c|}{ A. Base spatial horizon measuring effects relative to districts $50+\mathrm{km}$ from the GQ network } \\
\hline $\begin{array}{l}\text { Post GQ upgrades * } \\
\text { Nodal district }\end{array}$ & $\begin{array}{c}0.560 \\
(0.501)\end{array}$ & $\begin{array}{c}0.560 \\
(0.462)\end{array}$ & $\begin{array}{c}0.654 \\
(0.453)\end{array}$ & $\begin{array}{c}0.702 \\
(0.662)\end{array}$ & $\begin{array}{c}1.167 \\
(0.814)\end{array}$ & $\begin{array}{c}1.647 \\
(0.951)\end{array}$ & $\begin{array}{c}0.084 \\
(0.135)\end{array}$ & $\begin{array}{l}-0.022 \\
(0.033)\end{array}$ \\
\hline $\begin{array}{l}\text { Post GQ upgrades * } \\
\text { District } 0-10 \mathrm{~km} \text { from GQ }\end{array}$ & $\begin{array}{c}0.094 \\
(0.112)\end{array}$ & $\begin{array}{l}-0.039 \\
(0.131)\end{array}$ & $\begin{array}{c}0.166 \\
(0.176)\end{array}$ & $\begin{array}{c}0.436 \\
(0.172)\end{array}$ & $\begin{array}{c}0.471 \\
(0.239)\end{array}$ & $\begin{array}{c}0.928 \\
(0.346)\end{array}$ & $\begin{array}{c}0.177 \\
(0.093)\end{array}$ & $\begin{array}{c}0.086 \\
(0.042)\end{array}$ \\
\hline $\begin{array}{l}\text { Post GQ upgrades * } \\
\text { District } 10-50 \mathrm{~km} \text { from GQ }\end{array}$ & $\begin{array}{l}-0.023 \\
(0.129)\end{array}$ & $\begin{array}{l}-0.078 \\
(0.135)\end{array}$ & $\begin{array}{l}-0.006 \\
(0.191)\end{array}$ & $\begin{array}{l}-0.012 \\
(0.240)\end{array}$ & $\begin{array}{l}-0.056 \\
(0.357)\end{array}$ & $\begin{array}{l}-0.263 \\
(0.537)\end{array}$ & $\begin{array}{c}0.043 \\
(0.132)\end{array}$ & $\begin{array}{l}-0.005 \\
(0.074)\end{array}$ \\
\hline District and year fixed effects & Yes & Yes & Yes & Yes & Yes & Yes & Yes & Yes \\
\hline Observations & 1248 & 1248 & 1248 & 1248 & 1248 & 1248 & 1248 & 1244 \\
\hline & \multicolumn{8}{|c|}{ B. Extended spatial horizon measuring effects relative to districts $200+\mathrm{km}$ from the GQ network } \\
\hline $\begin{array}{l}\text { Post GQ upgrades * } \\
\text { Nodal district }\end{array}$ & $\begin{array}{c}0.513 \\
(0.505)\end{array}$ & $\begin{array}{c}0.576 \\
(0.468)\end{array}$ & $\begin{array}{c}0.744 \\
(0.458)\end{array}$ & $\begin{array}{c}0.621 \\
(0.668)\end{array}$ & $\begin{array}{c}1.071 \\
(0.824)\end{array}$ & $\begin{array}{c}1.419 \\
(0.968)\end{array}$ & $\begin{array}{c}0.158 \\
(0.144)\end{array}$ & $\begin{array}{l}-0.003 \\
(0.041)\end{array}$ \\
\hline $\begin{array}{l}\text { Post GQ upgrades * } \\
\text { District } 0-10 \mathrm{~km} \text { from GQ }\end{array}$ & $\begin{array}{c}0.047 \\
(0.128)\end{array}$ & $\begin{array}{l}-0.022 \\
(0.144)\end{array}$ & $\begin{array}{c}0.257 \\
(0.177)\end{array}$ & $\begin{array}{c}0.355 \\
(0.186)\end{array}$ & $\begin{array}{c}0.376 \\
(0.266)\end{array}$ & $\begin{array}{c}0.702 \\
(0.382)\end{array}$ & $\begin{array}{c}0.253 \\
(0.103)\end{array}$ & $\begin{array}{c}0.104 \\
(0.048)\end{array}$ \\
\hline $\begin{array}{l}\text { Post GQ upgrades * } \\
\text { District } 10-50 \mathrm{~km} \text { from GQ }\end{array}$ & $\begin{array}{l}-0.071 \\
(0.144)\end{array}$ & $\begin{array}{l}-0.062 \\
(0.153)\end{array}$ & $\begin{array}{c}0.084 \\
(0.202)\end{array}$ & $\begin{array}{l}-0.094 \\
(0.253)\end{array}$ & $\begin{array}{l}-0.151 \\
(0.379)\end{array}$ & $\begin{array}{l}-0.490 \\
(0.566)\end{array}$ & $\begin{array}{c}0.118 \\
(0.141)\end{array}$ & $\begin{array}{c}0.013 \\
(0.078)\end{array}$ \\
\hline $\begin{array}{l}\text { Post GQ upgrades * } \\
\text { District } 50-125 \mathrm{~km} \text { from GQ }\end{array}$ & $\begin{array}{l}-0.209 \\
(0.157)\end{array}$ & $\begin{array}{l}-0.108 \\
(0.136)\end{array}$ & $\begin{array}{l}-0.018 \\
(0.183)\end{array}$ & $\begin{array}{l}-0.185 \\
(0.214)\end{array}$ & $\begin{array}{l}-0.282 \\
(0.310)\end{array}$ & $\begin{array}{l}-0.545 \\
(0.513)\end{array}$ & $\begin{array}{c}0.076 \\
(0.149)\end{array}$ & $\begin{array}{c}0.043 \\
(0.076)\end{array}$ \\
\hline $\begin{array}{l}\text { Post GQ upgrades * } \\
\text { District } 125-200 \mathrm{~km} \text { from GQ }\end{array}$ & $\begin{array}{c}0.014 \\
(0.140)\end{array}$ & $\begin{array}{c}0.163 \\
(0.155)\end{array}$ & $\begin{array}{c}0.361 \\
(0.200)\end{array}$ & $\begin{array}{l}-0.136 \\
(0.229)\end{array}$ & $\begin{array}{l}-0.101 \\
(0.360)\end{array}$ & $\begin{array}{l}-0.356 \\
(0.513)\end{array}$ & $\begin{array}{c}0.214 \\
(0.129)\end{array}$ & $\begin{array}{c}0.029 \\
(0.066)\end{array}$ \\
\hline District and year fixed effects & Yes & Yes & Yes & Yes & Yes & Yes & Yes & Yes \\
\hline Observations & 1248 & 1248 & 1248 & 1248 & 1248 & 1248 & 1248 & 1244 \\
\hline
\end{tabular}

Notes: See Table 1a. Estimations consider the location and productivity of organized-sector manufacturing activity in 312 Indian districts for 1994, 2000,2005 , and 2007 from the Annual Survey of Industries. Young plants are those less than four years old. Panel A estimates effects of GQ upgrades for nearby districts relative to districts more than $50 \mathrm{~km}$ from the GQ network; Panel B includes extended spatial rings to measure effects relative to districts $200 \mathrm{~km}$ away from the GQ network. The Post GQ upgrades variable takes unit value for the years 2005 and 2007 after the GQ upgrades commenced in 2001. Labor productivity is total output per employee, and TFP is the average residual in each district from a weighted regression of log of value added on logs of employment and capital for each industry and year. Outcome variables are winsorized at their 1\% and $99 \%$ levels, and entry variables are coded at the 1\% level where no entry is observed to maintain a consistent sample. Estimations report standard errors clustered by district, include district and year fixed effects, and weight observations by log total district population in 2001. 
Table 2b: Pre-post estimations split by new construction versus improvements

\begin{tabular}{|c|c|c|c|c|c|c|c|c|}
\hline & \multicolumn{3}{|c|}{ Log levels of total activity } & \multicolumn{3}{|c|}{ Log levels of young firm activity } & \multirow{2}{*}{$\begin{array}{l}\text { Log labor } \\
\text { productivity }\end{array}$} & \multirow{2}{*}{$\begin{array}{l}\text { Total factor } \\
\text { productivity }\end{array}$} \\
\hline & Plants & Employment & Output & Plants & Employment & Output & & \\
\hline & $(1)$ & $(2)$ & (3) & (4) & $(5)$ & $(6)$ & $(7)$ & $(8)$ \\
\hline $\begin{array}{l}\text { Post GQ upgrades * } \\
\text { Nodal district }\end{array}$ & $\begin{array}{c}0.560 \\
(0.501)\end{array}$ & $\begin{array}{c}0.560 \\
(0.462)\end{array}$ & $\begin{array}{c}0.654 \\
(0.454)\end{array}$ & $\begin{array}{c}0.702 \\
(0.663)\end{array}$ & $\begin{array}{l}1.167 \\
(0.814)\end{array}$ & $\begin{array}{c}1.647 \\
(0.951)\end{array}$ & $\begin{array}{c}0.084 \\
(0.135)\end{array}$ & $\begin{array}{c}0.011 \\
(0.033)\end{array}$ \\
\hline $\begin{array}{l}\text { Post GQ upgrades * } \\
\text { District } 0-10 \mathrm{~km} \text { from GQ * } \\
\text { New highway construction }\end{array}$ & $\begin{array}{c}0.188 \\
(0.114)\end{array}$ & $\begin{array}{c}0.102 \\
(0.130)\end{array}$ & $\begin{array}{c}0.307 \\
(0.153)\end{array}$ & $\begin{array}{c}0.474 \\
(0.161)\end{array}$ & $\begin{array}{c}0.440 \\
(0.208)\end{array}$ & $\begin{array}{c}0.777 \\
(0.284)\end{array}$ & $\begin{array}{c}0.189 \\
(0.087)\end{array}$ & $\begin{array}{c}0.094 \\
(0.041)\end{array}$ \\
\hline $\begin{array}{l}\text { Post GQ upgrades * } \\
\text { District } 0-10 \mathrm{~km} \text { from GQ * } \\
\text { Improvement of existing highway }\end{array}$ & $\begin{array}{c}0.009 \\
(0.160)\end{array}$ & $\begin{array}{l}-0.167 \\
(0.191)\end{array}$ & $\begin{array}{c}0.038 \\
(0.272)\end{array}$ & $\begin{array}{c}0.402 \\
(0.266)\end{array}$ & $\begin{array}{c}0.500 \\
(0.370)\end{array}$ & $\begin{array}{c}1.066 \\
(0.533)\end{array}$ & $\begin{array}{c}0.167 \\
(0.138)\end{array}$ & $\begin{array}{c}0.061 \\
(0.054)\end{array}$ \\
\hline $\begin{array}{l}\text { Post GQ upgrades * } \\
\text { District } 10-50 \mathrm{~km} \text { from GQ }\end{array}$ & $\begin{array}{l}-0.023 \\
(0.129)\end{array}$ & $\begin{array}{l}-0.078 \\
(0.135)\end{array}$ & $\begin{array}{l}-0.006 \\
(0.191)\end{array}$ & $\begin{array}{l}-0.012 \\
(0.240)\end{array}$ & $\begin{array}{l}-0.056 \\
(0.358)\end{array}$ & $\begin{array}{l}-0.263 \\
(0.537)\end{array}$ & $\begin{array}{c}0.043 \\
(0.132)\end{array}$ & $\begin{array}{c}0.009 \\
(0.070)\end{array}$ \\
\hline $\begin{array}{l}\text { District and year fixed effects } \\
\text { Observations }\end{array}$ & $\begin{array}{c}\text { Yes } \\
1248\end{array}$ & $\begin{array}{c}\text { Yes } \\
1248\end{array}$ & $\begin{array}{c}\text { Yes } \\
1248\end{array}$ & $\begin{array}{c}\text { Yes } \\
1248\end{array}$ & $\begin{array}{c}\text { Yes } \\
1248\end{array}$ & $\begin{array}{c}\text { Yes } \\
1248\end{array}$ & $\begin{array}{c}\text { Yes } \\
1248\end{array}$ & $\begin{array}{c}\text { Yes } \\
1244\end{array}$ \\
\hline
\end{tabular}

Notes: See Table 2a. Estimations split local effects along the GQ network by whether the development is new highway construction or the improvement of existing highways. Effects are measured relative to districts 50+ km from the GQ network. 
Table 3a: Estimations of dynamic impact of GQ improvements on manufacturing activity

\begin{tabular}{|c|c|c|c|c|c|c|c|c|}
\hline & \multicolumn{3}{|c|}{ Log levels of total activity } & \multicolumn{3}{|c|}{ Log levels of young firm activity } & \multirow{2}{*}{$\begin{array}{l}\text { Log labor } \\
\text { productivity }\end{array}$} & \multirow{2}{*}{$\begin{array}{l}\text { Total factor } \\
\text { productivity }\end{array}$} \\
\hline & Plants & Employment & Output & Plants & Employment & Output & & \\
\hline & $(1)$ & $(2)$ & (3) & $(4)$ & $(5)$ & $(6)$ & $(7)$ & $(8)$ \\
\hline \multicolumn{9}{|c|}{ Dynamics for districts $0-10 \mathrm{~km}$ from the GQ network: } \\
\hline $\begin{array}{l}\text { Year 2000* } \\
\text { District 0-10 km from GQ }\end{array}$ & $\begin{array}{c}0.057 \\
(0.168)\end{array}$ & $\begin{array}{c}0.179 \\
(0.207)\end{array}$ & $\begin{array}{l}-0.106 \\
(0.298)\end{array}$ & $\begin{array}{l}-0.110 \\
(0.257)\end{array}$ & $\begin{array}{l}-0.107 \\
(0.319)\end{array}$ & $\begin{array}{l}-0.087 \\
(0.480)\end{array}$ & $\begin{array}{l}-0.276 \\
(0.160)\end{array}$ & $\begin{array}{l}-0.098 \\
(0.065)\end{array}$ \\
\hline $\begin{array}{l}\text { Year } 2005 * \\
\text { District 0-10 km from GQ }\end{array}$ & $\begin{array}{c}0.092 \\
(0.140)\end{array}$ & $\begin{array}{c}0.008 \\
(0.173)\end{array}$ & $\begin{array}{c}0.031 \\
(0.248)\end{array}$ & $\begin{array}{c}0.303 \\
(0.222)\end{array}$ & $\begin{array}{c}0.444 \\
(0.293)\end{array}$ & $\begin{array}{c}1.032 \\
(0.454)\end{array}$ & $\begin{array}{c}0.018 \\
(0.114)\end{array}$ & $\begin{array}{c}0.066 \\
(0.051)\end{array}$ \\
\hline $\begin{array}{l}\text { Year } 2007 * \\
\text { District } 0-10 \mathrm{~km} \text { from GQ }\end{array}$ & $\begin{array}{c}0.151 \\
(0.143)\end{array}$ & $\begin{array}{c}0.086 \\
(0.182)\end{array}$ & $\begin{array}{c}0.198 \\
(0.274)\end{array}$ & $\begin{array}{c}0.463 \\
(0.242)\end{array}$ & $\begin{array}{c}0.396 \\
(0.317)\end{array}$ & $\begin{array}{c}0.741 \\
(0.440)\end{array}$ & $\begin{array}{c}0.070 \\
(0.141)\end{array}$ & $\begin{array}{c}0.011 \\
(0.055)\end{array}$ \\
\hline \multicolumn{9}{|c|}{ Dynamics for districts $10-50 \mathrm{~km}$ from the GQ network: } \\
\hline $\begin{array}{l}\text { Year } 2000 * \\
\text { District } 10-50 \mathrm{~km} \text { from GQ }\end{array}$ & $\begin{array}{c}0.090 \\
(0.231)\end{array}$ & $\begin{array}{c}0.238 \\
(0.195)\end{array}$ & $\begin{array}{c}0.049 \\
(0.269)\end{array}$ & $\begin{array}{c}0.137 \\
(0.281)\end{array}$ & $\begin{array}{l}-0.150 \\
(0.386)\end{array}$ & $\begin{array}{l}-0.214 \\
(0.656)\end{array}$ & $\begin{array}{l}-0.193 \\
(0.145)\end{array}$ & $\begin{array}{l}-0.044 \\
(0.095)\end{array}$ \\
\hline $\begin{array}{l}\text { Year } 2005 * \\
\text { District } 10-50 \mathrm{~km} \text { from GQ }\end{array}$ & $\begin{array}{c}0.061 \\
(0.132)\end{array}$ & $\begin{array}{c}0.024 \\
(0.144)\end{array}$ & $\begin{array}{l}-0.026 \\
(0.200)\end{array}$ & $\begin{array}{c}0.050 \\
(0.274)\end{array}$ & $\begin{array}{l}-0.136 \\
(0.425)\end{array}$ & $\begin{array}{l}-0.341 \\
(0.695)\end{array}$ & $\begin{array}{l}-0.081 \\
(0.116)\end{array}$ & $\begin{array}{c}0.018 \\
(0.079)\end{array}$ \\
\hline $\begin{array}{l}\text { Year } 2007 * \\
\text { District } 10-50 \mathrm{~km} \text { from GQ }\end{array}$ & $\begin{array}{l}-0.018 \\
(0.144)\end{array}$ & $\begin{array}{c}0.056 \\
(0.133)\end{array}$ & $\begin{array}{c}0.062 \\
(0.183)\end{array}$ & $\begin{array}{c}0.064 \\
(0.276)\end{array}$ & $\begin{array}{l}-0.124 \\
(0.417)\end{array}$ & $\begin{array}{l}-0.398 \\
(0.562)\end{array}$ & $\begin{array}{l}-0.022 \\
(0.164)\end{array}$ & $\begin{array}{l}-0.072 \\
(0.087)\end{array}$ \\
\hline District and year fixed effects & Yes & Yes & Yes & Yes & Yes & Yes & Yes & Yes \\
\hline Observations & 1248 & 1248 & 1248 & 1248 & 1248 & 1248 & 1248 & 1244 \\
\hline
\end{tabular}

Notes: See Table 2a. Estimates include unreported interactions of year effects and nodal districts. Effects are estimated relative to districts more than $50 \mathrm{~km}$ from the GQ network. 
Table 3b: Dynamic estimations using dates of GQ project completion by district

\begin{tabular}{|c|c|c|c|c|c|c|c|c|}
\hline & \multicolumn{3}{|c|}{ Log levels of total activity } & \multicolumn{3}{|c|}{ Log levels of young firm activity } & \multirow{2}{*}{$\begin{array}{c}\text { Log labor } \\
\text { productivity }\end{array}$} & \multirow{2}{*}{$\begin{array}{l}\text { Total factor } \\
\text { productivity }\end{array}$} \\
\hline & Plants & Employment & Output & Plants & Employment & Output & & \\
\hline & $(1)$ & $(2)$ & (3) & $(4)$ & $(5)$ & $(6)$ & $(7)$ & $(8)$ \\
\hline $\begin{array}{l}\text { Post GQ upgrades * } \\
\text { Nodal district }\end{array}$ & $\begin{array}{c}0.560 \\
(0.501)\end{array}$ & $\begin{array}{c}0.560 \\
(0.463)\end{array}$ & $\begin{array}{c}0.654 \\
(0.454)\end{array}$ & $\begin{array}{c}0.702 \\
(0.663)\end{array}$ & $\begin{array}{l}1.167 \\
(0.815)\end{array}$ & $\begin{array}{c}1.647 \\
(0.952)\end{array}$ & $\begin{array}{c}0.084 \\
(0.135)\end{array}$ & $\begin{array}{c}0.011 \\
(0.033)\end{array}$ \\
\hline $\begin{array}{l}\text { Post GQ upgrades * } \\
\text { District } 0-10 \text { km from GQ * } \\
\text { Section completed by March } 2003\end{array}$ & $\begin{array}{c}0.194 \\
(0.154)\end{array}$ & $\begin{array}{c}0.171 \\
(0.148)\end{array}$ & $\begin{array}{c}0.391 \\
(0.200)\end{array}$ & $\begin{array}{c}0.540 \\
(0.229)\end{array}$ & $\begin{array}{c}0.658 \\
(0.289)\end{array}$ & $\begin{array}{c}1.163 \\
(0.429)\end{array}$ & $\begin{array}{c}0.198 \\
(0.140)\end{array}$ & $\begin{array}{c}0.061 \\
(0.043)\end{array}$ \\
\hline $\begin{array}{l}\text { Post GQ upgrades * } \\
\text { District 0-10 km from GQ * } \\
\text { Section completed 2003-2006 (March) }\end{array}$ & $\begin{array}{c}0.079 \\
(0.167)\end{array}$ & $\begin{array}{l}-0.124 \\
(0.226)\end{array}$ & $\begin{array}{l}-0.023 \\
(0.304)\end{array}$ & $\begin{array}{c}0.429 \\
(0.253)\end{array}$ & $\begin{array}{c}0.401 \\
(0.377)\end{array}$ & $\begin{array}{c}0.766 \\
(0.545)\end{array}$ & $\begin{array}{c}0.087 \\
(0.125)\end{array}$ & $\begin{array}{c}0.082 \\
(0.047)\end{array}$ \\
\hline $\begin{array}{l}\text { Post GQ upgrades * } \\
\text { District } 0-10 \mathrm{~km} \text { from GQ * } \\
\text { Section completed after March } 2006\end{array}$ & $\begin{array}{l}-0.053 \\
(0.179)\end{array}$ & $\begin{array}{l}-0.259 \\
(0.192)\end{array}$ & $\begin{array}{c}0.099 \\
(0.284)\end{array}$ & $\begin{array}{c}0.267 \\
(0.357)\end{array}$ & $\begin{array}{c}0.267 \\
(0.451)\end{array}$ & $\begin{array}{c}0.801 \\
(0.597)\end{array}$ & $\begin{array}{c}0.300 \\
(0.146)\end{array}$ & $\begin{array}{c}0.098 \\
(0.098)\end{array}$ \\
\hline $\begin{array}{l}\text { Post GQ upgrades * } \\
\text { District } 10-50 \mathrm{~km} \text { from GQ }\end{array}$ & $\begin{array}{l}-0.023 \\
(0.129)\end{array}$ & $\begin{array}{l}-0.078 \\
(0.135)\end{array}$ & $\begin{array}{l}-0.007 \\
(0.191)\end{array}$ & $\begin{array}{l}-0.012 \\
(0.240)\end{array}$ & $\begin{array}{l}-0.056 \\
(0.358)\end{array}$ & $\begin{array}{l}-0.263 \\
(0.538)\end{array}$ & $\begin{array}{c}0.044 \\
(0.132)\end{array}$ & $\begin{array}{c}0.009 \\
(0.070)\end{array}$ \\
\hline $\begin{array}{l}\text { District and year fixed effects } \\
\text { Observations }\end{array}$ & $\begin{array}{c}\text { Yes } \\
1248\end{array}$ & $\begin{array}{c}\text { Yes } \\
1248\end{array}$ & $\begin{array}{c}\text { Yes } \\
1248\end{array}$ & $\begin{array}{c}\text { Yes } \\
1248\end{array}$ & $\begin{array}{c}\text { Yes } \\
1248\end{array}$ & $\begin{array}{c}\text { Yes } \\
1248\end{array}$ & $\begin{array}{c}\text { Yes } \\
1248\end{array}$ & $\begin{array}{c}\text { Yes } \\
1244\end{array}$ \\
\hline
\end{tabular}

Notes: See Table 2a. 
Table 4: Estimations of impact of GQ improvements compared to the NS-EW highway not improved

\begin{tabular}{|c|c|c|c|c|c|c|c|c|}
\hline & \multicolumn{3}{|c|}{ Log levels of total activity } & \multicolumn{3}{|c|}{ Log levels of young firm activity } & \multirow{2}{*}{$\begin{array}{l}\text { Log labor } \\
\text { productivity }\end{array}$} & \multirow{2}{*}{$\begin{array}{l}\text { Total factor } \\
\text { productivity }\end{array}$} \\
\hline & Plants & Employment & Output & Plants & Employment & Output & & \\
\hline & $(1)$ & $(2)$ & (3) & $(4)$ & $(5)$ & $(6)$ & (7) & $(8)$ \\
\hline \multicolumn{9}{|c|}{ Effects for districts based upon distance from the GQ network: } \\
\hline $\begin{array}{l}\text { Post GQ upgrades * } \\
\text { Nodal district GQ }\end{array}$ & $\begin{array}{c}0.354 \\
(0.389)\end{array}$ & $\begin{array}{c}0.193 \\
(0.374)\end{array}$ & $\begin{array}{c}0.289 \\
(0.359)\end{array}$ & $\begin{array}{c}0.367 \\
(0.613)\end{array}$ & $\begin{array}{c}0.736 \\
(0.828)\end{array}$ & $\begin{array}{c}1.253 \\
(0.943)\end{array}$ & $\begin{array}{c}0.119 \\
(0.154)\end{array}$ & $\begin{array}{l}-0.070 \\
(0.057)\end{array}$ \\
\hline $\begin{array}{l}\text { Post GQ upgrades * } \\
\text { District } 0-10 \mathrm{~km} \text { from GQ }\end{array}$ & $\begin{array}{c}0.099 \\
(0.117)\end{array}$ & $\begin{array}{l}-0.031 \\
(0.136)\end{array}$ & $\begin{array}{c}0.160 \\
(0.181)\end{array}$ & $\begin{array}{c}0.370 \\
(0.181)\end{array}$ & $\begin{array}{c}0.407 \\
(0.256)\end{array}$ & $\begin{array}{c}0.860 \\
(0.372)\end{array}$ & $\begin{array}{c}0.165 \\
(0.095)\end{array}$ & $\begin{array}{c}0.066 \\
(0.040)\end{array}$ \\
\hline $\begin{array}{l}\text { Post GQ upgrades * } \\
\text { District } 10-50 \mathrm{~km} \text { from GQ }\end{array}$ & $\begin{array}{l}-0.013 \\
(0.130)\end{array}$ & $\begin{array}{l}-0.059 \\
(0.136)\end{array}$ & $\begin{array}{c}0.013 \\
(0.192)\end{array}$ & $\begin{array}{l}-0.045 \\
(0.246)\end{array}$ & $\begin{array}{l}-0.069 \\
(0.365)\end{array}$ & $\begin{array}{l}-0.274 \\
(0.547)\end{array}$ & $\begin{array}{c}0.044 \\
(0.132)\end{array}$ & $\begin{array}{c}0.005 \\
(0.070)\end{array}$ \\
\hline \multicolumn{9}{|c|}{ Effects for districts based upon distance from the NS-EW network: } \\
\hline $\begin{array}{l}\text { Post GQ upgrades * } \\
\text { Nodal district NS-EW }\end{array}$ & $\begin{array}{c}0.398 \\
(0.434)\end{array}$ & $\begin{array}{c}0.712 \\
(0.486)\end{array}$ & $\begin{array}{c}0.653 \\
(0.406)\end{array}$ & $\begin{array}{c}0.389 \\
(0.684)\end{array}$ & $\begin{array}{c}0.584 \\
(0.779)\end{array}$ & $\begin{array}{c}0.507 \\
(0.732)\end{array}$ & $\begin{array}{l}-0.116 \\
(0.143)\end{array}$ & $\begin{array}{c}0.107 \\
(0.064)\end{array}$ \\
\hline $\begin{array}{l}\text { Post GQ upgrades * } \\
\text { District } 0-10 \mathrm{~km} \text { from NS-EW } * \\
\text { Section scheduled for Phase I }\end{array}$ & $\begin{array}{l}-0.128 \\
(0.125)\end{array}$ & $\begin{array}{c}0.054 \\
(0.110)\end{array}$ & $\begin{array}{c}0.020 \\
(0.169)\end{array}$ & $\begin{array}{l}-0.338 \\
(0.198)\end{array}$ & $\begin{array}{l}-0.314 \\
(0.327)\end{array}$ & $\begin{array}{l}-0.422 \\
(0.479)\end{array}$ & $\begin{array}{l}-0.043 \\
(0.138)\end{array}$ & $\begin{array}{l}-0.081 \\
(0.054)\end{array}$ \\
\hline $\begin{array}{l}\text { Post GQ upgrades * } \\
\text { District } 0-10 \mathrm{~km} \text { from NS-EW } * \\
\text { Section scheduled for Phase II }\end{array}$ & $\begin{array}{c}0.115 \\
(0.140)\end{array}$ & $\begin{array}{c}0.086 \\
(0.165)\end{array}$ & $\begin{array}{c}0.061 \\
(0.203)\end{array}$ & $\begin{array}{l}-0.233 \\
(0.223)\end{array}$ & $\begin{array}{l}-0.152 \\
(0.332)\end{array}$ & $\begin{array}{l}-0.148 \\
(0.468)\end{array}$ & $\begin{array}{l}-0.017 \\
(0.140)\end{array}$ & $\begin{array}{l}-0.049 \\
(0.069)\end{array}$ \\
\hline $\begin{array}{l}\text { Post GQ upgrades * } \\
\text { District } 10-50 \mathrm{~km} \text { from NS-EW }\end{array}$ & $\begin{array}{c}0.007 \\
(0.142)\end{array}$ & $\begin{array}{l}-0.050 \\
(0.143)\end{array}$ & $\begin{array}{l}-0.162 \\
(0.183)\end{array}$ & $\begin{array}{l}-0.229 \\
(0.214)\end{array}$ & $\begin{array}{l}-0.284 \\
(0.310)\end{array}$ & $\begin{array}{l}-0.224 \\
(0.499)\end{array}$ & $\begin{array}{l}-0.094 \\
(0.121)\end{array}$ & $\begin{array}{l}-0.029 \\
(0.054)\end{array}$ \\
\hline $\begin{array}{l}\text { District and year fixed effects } \\
\text { Observations }\end{array}$ & $\begin{array}{c}\text { Yes } \\
1248\end{array}$ & $\begin{array}{c}\text { Yes } \\
1248\end{array}$ & $\begin{array}{c}\text { Yes } \\
1248\end{array}$ & $\begin{array}{c}\text { Yes } \\
1248\end{array}$ & $\begin{array}{c}\text { Yes } \\
1248\end{array}$ & $\begin{array}{c}\text { Yes } \\
1248\end{array}$ & $\begin{array}{c}\text { Yes } \\
1248\end{array}$ & $\begin{array}{c}\text { Yes } \\
1244\end{array}$ \\
\hline
\end{tabular}

Notes: See Table 2. Estimations compare results from proximity to the GQ network to a second NS-EW highway network that was planned for partial upgrade at the same time as the GQ project but was then delayed. 
Table 5: Estimations of location decisions of new plants by industry land and building intensity

\begin{tabular}{|c|c|c|c|c|c|c|c|c|c|}
\hline & \multicolumn{3}{|c|}{$\begin{array}{l}\text { Log new establishment counts } \\
\text { by industry land/building intensity }\end{array}$} & \multicolumn{3}{|c|}{$\begin{array}{l}\text { Log new employment levels } \\
\text { by industry land/building intensity }\end{array}$} & \multicolumn{3}{|c|}{$\begin{array}{l}\text { Log new output levels } \\
\text { by industry land/building intensity }\end{array}$} \\
\hline & $0-25$ th & 25 th-75th & 75 th & $0-25$ th & 25 th-75th & 75 th & $0-25$ th & 25 th-75th & 75 th \\
\hline & $(1)$ & $(2)$ & (3) & (4) & $(5)$ & $(6)$ & $(7)$ & $(8)$ & $(9)$ \\
\hline & \multicolumn{9}{|c|}{ A. Base spatial horizon measuring effects relative to districts $50 \mathrm{~km}$ from the GQ network } \\
\hline $\begin{array}{l}\text { Post GQ upgrades * } \\
\text { Nodal district }\end{array}$ & $\begin{array}{c}1.102 \\
(0.565)\end{array}$ & $\begin{array}{c}0.670 \\
(0.662)\end{array}$ & $\begin{array}{c}0.063 \\
(0.663)\end{array}$ & $\begin{array}{c}1.839 \\
(0.877)\end{array}$ & $\begin{array}{c}1.345 \\
(0.786)\end{array}$ & $\begin{array}{c}0.664 \\
(0.756)\end{array}$ & $\begin{array}{c}2.258 \\
(1.471)\end{array}$ & $\begin{array}{c}1.593 \\
(0.885)\end{array}$ & $\begin{array}{c}1.213 \\
(1.019)\end{array}$ \\
\hline $\begin{array}{l}\text { Post GQ upgrades * } \\
\text { District } 0-10 \mathrm{~km} \text { from GQ }\end{array}$ & $\begin{array}{c}0.058 \\
(0.183)\end{array}$ & $\begin{array}{c}0.330 \\
(0.158)\end{array}$ & $\begin{array}{c}0.585 \\
(0.195)\end{array}$ & $\begin{array}{c}0.224 \\
(0.296)\end{array}$ & $\begin{array}{c}0.485 \\
(0.244)\end{array}$ & $\begin{array}{c}0.698 \\
(0.303)\end{array}$ & $\begin{array}{c}0.283 \\
(0.511)\end{array}$ & $\begin{array}{c}0.822 \\
(0.341)\end{array}$ & $\begin{array}{r}1.047 \\
(0.443)\end{array}$ \\
\hline $\begin{array}{l}\text { Post GQ upgrades * } \\
\text { District } 10-50 \mathrm{~km} \text { from GQ }\end{array}$ & $\begin{array}{l}-0.203 \\
(0.143)\end{array}$ & $\begin{array}{l}-0.159 \\
(0.209)\end{array}$ & $\begin{array}{c}0.101 \\
(0.208)\end{array}$ & $\begin{array}{l}-0.155 \\
(0.271)\end{array}$ & $\begin{array}{l}-0.262 \\
(0.366)\end{array}$ & $\begin{array}{c}0.121 \\
(0.300)\end{array}$ & $\begin{array}{l}-0.482 \\
(0.465)\end{array}$ & $\begin{array}{l}-0.384 \\
(0.523)\end{array}$ & $\begin{array}{r}0.174 \\
(0.411)\end{array}$ \\
\hline $\begin{array}{l}\text { District and year fixed effects } \\
\text { Observations }\end{array}$ & $\begin{array}{c}\text { Yes } \\
1248\end{array}$ & $\begin{array}{c}\text { Yes } \\
1248\end{array}$ & $\begin{array}{c}\text { Yes } \\
1248\end{array}$ & $\begin{array}{c}\text { Yes } \\
1248\end{array}$ & $\begin{array}{c}\text { Yes } \\
1248\end{array}$ & $\begin{array}{c}\text { Yes } \\
1248\end{array}$ & $\begin{array}{l}\text { Yes } \\
1248\end{array}$ & $\begin{array}{c}\text { Yes } \\
1248\end{array}$ & $\begin{array}{c}\text { Yes } \\
1248\end{array}$ \\
\hline & \multicolumn{9}{|c|}{ B. Extended spatial horizon measuring effects relative to districts $200 \mathrm{~km}$ from the GQ network } \\
\hline $\begin{array}{l}\text { Post GQ upgrades * } \\
\text { Nodal district }\end{array}$ & $\begin{array}{c}1.182 \\
(0.570)\end{array}$ & $\begin{array}{c}0.549 \\
(0.669)\end{array}$ & $\begin{array}{c}0.032 \\
(0.669)\end{array}$ & $\begin{array}{c}1.847 \\
(0.883)\end{array}$ & $\begin{array}{l}1.235 \\
(0.802)\end{array}$ & $\begin{array}{c}0.684 \\
(0.770)\end{array}$ & $\begin{array}{c}2.257 \\
(1.483)\end{array}$ & $\begin{array}{l}1.455 \\
(0.907)\end{array}$ & $\begin{array}{r}1.097 \\
(1.041)\end{array}$ \\
\hline $\begin{array}{l}\text { Post GQ upgrades * } \\
\text { District } 0-10 \mathrm{~km} \text { from GQ }\end{array}$ & $\begin{array}{c}0.138 \\
(0.196)\end{array}$ & $\begin{array}{c}0.209 \\
(0.180)\end{array}$ & $\begin{array}{c}0.555 \\
(0.211)\end{array}$ & $\begin{array}{c}0.232 \\
(0.314)\end{array}$ & $\begin{array}{c}0.375 \\
(0.283)\end{array}$ & $\begin{array}{c}0.718 \\
(0.334)\end{array}$ & $\begin{array}{c}0.281 \\
(0.545)\end{array}$ & $\begin{array}{c}0.684 \\
(0.384)\end{array}$ & $\begin{array}{c}0.930 \\
(0.486)\end{array}$ \\
\hline $\begin{array}{l}\text { Post GQ upgrades * } \\
\text { District } 10-50 \mathrm{~km} \text { from GQ }\end{array}$ & $\begin{array}{l}-0.122 \\
(0.158)\end{array}$ & $\begin{array}{l}-0.280 \\
(0.229)\end{array}$ & $\begin{array}{c}0.070 \\
(0.223)\end{array}$ & $\begin{array}{l}-0.148 \\
(0.287)\end{array}$ & $\begin{array}{l}-0.373 \\
(0.397)\end{array}$ & $\begin{array}{c}0.141 \\
(0.333)\end{array}$ & $\begin{array}{l}-0.484 \\
(0.497)\end{array}$ & $\begin{array}{l}-0.522 \\
(0.558)\end{array}$ & $\begin{array}{c}0.058 \\
(0.461)\end{array}$ \\
\hline $\begin{array}{l}\text { Post GQ upgrades * } \\
\text { District } 50-125 \mathrm{~km} \text { from GQ }\end{array}$ & $\begin{array}{c}0.148 \\
(0.184)\end{array}$ & $\begin{array}{l}-0.241 \\
(0.212)\end{array}$ & $\begin{array}{l}-0.102 \\
(0.193)\end{array}$ & $\begin{array}{c}0.020 \\
(0.311)\end{array}$ & $\begin{array}{l}-0.202 \\
(0.336)\end{array}$ & $\begin{array}{c}0.056 \\
(0.297)\end{array}$ & $\begin{array}{c}0.057 \\
(0.531)\end{array}$ & $\begin{array}{l}-0.264 \\
(0.495)\end{array}$ & $\begin{array}{l}-0.159 \\
(0.484)\end{array}$ \\
\hline $\begin{array}{l}\text { Post GQ upgrades * } \\
\text { District } 125-200 \mathrm{~km} \text { from GQ }\end{array}$ & $\begin{array}{c}0.166 \\
(0.164)\end{array}$ & $\begin{array}{l}-0.235 \\
(0.224)\end{array}$ & $\begin{array}{l}-0.022 \\
(0.180)\end{array}$ & $\begin{array}{c}0.010 \\
(0.293)\end{array}$ & $\begin{array}{l}-0.232 \\
(0.373)\end{array}$ & $\begin{array}{c}0.024 \\
(0.328)\end{array}$ & $\begin{array}{l}-0.060 \\
(0.469)\end{array}$ & $\begin{array}{l}-0.278 \\
(0.484)\end{array}$ & $\begin{array}{l}-0.294 \\
(0.495)\end{array}$ \\
\hline District and year fixed effects & Yes & Yes & Yes & Yes & Yes & Yes & Yes & Yes & Yes \\
\hline Observations & 1248 & 1248 & 1248 & 1248 & 1248 & 1248 & 1248 & 1248 & 1248 \\
\hline
\end{tabular}

Notes: See Table 2. Industries are divided into groups based upon land and building intensity in 2000 at the national level. These three bins include those with low land intensity (the bottom quartile of intensity), medium intensity (the middle two quartiles), and high intensity (the top quartile). 
Table 6: Estimations of impact of GQ improvements by district population density

\begin{tabular}{|c|c|c|c|c|c|}
\hline & $\begin{array}{c}\text { Log new } \\
\text { establishments }\end{array}$ & $\begin{array}{l}\text { Log new } \\
\text { employment }\end{array}$ & $\begin{array}{c}\text { Log new } \\
\text { output }\end{array}$ & $\begin{array}{l}\text { Log labor } \\
\text { productivity }\end{array}$ & $\begin{array}{l}\text { Total factor } \\
\text { productivity }\end{array}$ \\
\hline & $(1)$ & $(2)$ & (3) & $(4)$ & $(5)$ \\
\hline \multicolumn{6}{|l|}{ Effects for districts with low density: } \\
\hline $\begin{array}{l}\text { Post GQ upgrades * } \\
\text { Nodal district with low density }\end{array}$ & n.a. & n.a. & n.a. & n.a. & n.a. \\
\hline $\begin{array}{l}\text { Post GQ upgrades * } \\
\text { District } 0-10 \mathrm{~km} \text { from GQ with low density }\end{array}$ & $\begin{array}{c}0.240 \\
(0.303)\end{array}$ & $\begin{array}{c}0.146 \\
(0.387)\end{array}$ & $\begin{array}{c}0.361 \\
(0.566)\end{array}$ & $\begin{array}{c}0.249 \\
(0.127)\end{array}$ & $\begin{array}{c}0.118 \\
(0.043)\end{array}$ \\
\hline $\begin{array}{l}\text { Post GQ upgrades * } \\
\text { District } 10-50 \mathrm{~km} \text { from GQ with low density }\end{array}$ & $\begin{array}{c}0.104 \\
(0.266)\end{array}$ & $\begin{array}{c}0.107 \\
(0.437)\end{array}$ & $\begin{array}{c}0.027 \\
(0.691)\end{array}$ & $\begin{array}{c}0.091 \\
(0.139)\end{array}$ & $\begin{array}{l}-0.066 \\
(0.105)\end{array}$ \\
\hline \multicolumn{6}{|l|}{ Effects for districts with moderate density: } \\
\hline $\begin{array}{l}\text { Post GQ upgrades * } \\
\text { Nodal district with moderate density }\end{array}$ & $\begin{array}{c}0.616 \\
(0.090)\end{array}$ & $\begin{array}{l}1.560 \\
(0.137)\end{array}$ & $\begin{array}{c}1.488 \\
(0.207)\end{array}$ & $\begin{array}{l}-0.186 \\
(0.056)\end{array}$ & $\begin{array}{l}-0.057 \\
(0.028)\end{array}$ \\
\hline $\begin{array}{l}\text { Post GQ upgrades * } \\
\text { District } 0-10 \mathrm{~km} \text { from GQ with moderate density }\end{array}$ & $\begin{array}{c}0.468 \\
(0.215)\end{array}$ & $\begin{array}{c}0.624 \\
(0.331)\end{array}$ & $\begin{array}{c}1.067 \\
(0.448)\end{array}$ & $\begin{array}{c}0.086 \\
(0.137)\end{array}$ & $\begin{array}{c}0.034 \\
(0.059)\end{array}$ \\
\hline $\begin{array}{l}\text { Post GQ upgrades * } \\
\text { District } 10-50 \mathrm{~km} \text { from GQ with moderate density }\end{array}$ & $\begin{array}{l}-0.412 \\
(0.535)\end{array}$ & $\begin{array}{l}-0.273 \\
(0.676)\end{array}$ & $\begin{array}{l}-0.720 \\
(0.832)\end{array}$ & $\begin{array}{c}0.048 \\
(0.120)\end{array}$ & $\begin{array}{c}0.106 \\
(0.078)\end{array}$ \\
\hline \multicolumn{6}{|l|}{ Effects for districts with high density: } \\
\hline $\begin{array}{l}\text { Post GQ upgrades * } \\
\text { Nodal district with high density }\end{array}$ & $\begin{array}{c}0.713 \\
(0.744)\end{array}$ & $\begin{array}{c}1.119 \\
(0.911)\end{array}$ & $\begin{array}{c}1.667 \\
(1.065)\end{array}$ & $\begin{array}{c}0.117 \\
(0.144)\end{array}$ & $\begin{array}{l}-0.017 \\
(0.034)\end{array}$ \\
\hline $\begin{array}{l}\text { Post GQ upgrades * } \\
\text { District } 0-10 \mathrm{~km} \text { from GQ with high density }\end{array}$ & $\begin{array}{c}0.670 \\
(0.276)\end{array}$ & $\begin{array}{c}0.694 \\
(0.340)\end{array}$ & $\begin{array}{c}1.526 \\
(0.483)\end{array}$ & $\begin{array}{c}0.225 \\
(0.150)\end{array}$ & $\begin{array}{c}0.127 \\
(0.084)\end{array}$ \\
\hline $\begin{array}{l}\text { Post GQ upgrades * } \\
\text { District } 10-50 \mathrm{~km} \text { from GQ with high density }\end{array}$ & $\begin{array}{c}0.236 \\
(0.536)\end{array}$ & $\begin{array}{l}-0.261 \\
(0.898)\end{array}$ & $\begin{array}{l}-0.514 \\
(1.453)\end{array}$ & $\begin{array}{l}-0.126 \\
(0.546)\end{array}$ & $\begin{array}{c}0.023 \\
(0.180)\end{array}$ \\
\hline $\begin{array}{l}\text { District and year fixed effects } \\
\text { Observations }\end{array}$ & $\begin{array}{c}\text { Yes } \\
1248\end{array}$ & $\begin{array}{c}\text { Yes } \\
1248\end{array}$ & $\begin{array}{c}\text { Yes } \\
1248\end{array}$ & $\begin{array}{c}\text { Yes } \\
1248\end{array}$ & $\begin{array}{c}\text { Yes } \\
1248\end{array}$ \\
\hline
\end{tabular}

Notes: See Table 2. Districts are divided into groups based upon population density in 2000. Low-density districts are below the median density for India (up to 353 persons per square $\mathrm{km}$ ); moderate-density districts in the third quartile (353-693 persons per square km), and high-density districts in top quartile (over 693 persons per square $\mathrm{km}$ ). 
Appendix Table 1: Table 4 with a single measure for districts $0-10 \mathrm{~km}$ from NS-EW

\begin{tabular}{|c|c|c|c|c|c|c|c|c|}
\hline & \multicolumn{3}{|c|}{ Log levels of total activity } & \multicolumn{3}{|c|}{ Log levels of young firm activity } & \multirow{2}{*}{$\begin{array}{l}\text { Log labor } \\
\text { productivity }\end{array}$} & \multirow{2}{*}{$\begin{array}{l}\text { Total factor } \\
\text { productivity }\end{array}$} \\
\hline & Plants & Employment & Output & Plants & Employment & Output & & \\
\hline & $(1)$ & $(2)$ & (3) & (4) & $(5)$ & $(6)$ & (7) & $(8)$ \\
\hline \multicolumn{9}{|c|}{ Effects for districts based upon distance from the GQ network: } \\
\hline $\begin{array}{l}\text { Post GQ upgrades * } \\
\text { Nodal district GQ }\end{array}$ & $\begin{array}{c}0.352 \\
(0.389)\end{array}$ & $\begin{array}{c}0.193 \\
(0.374)\end{array}$ & $\begin{array}{c}0.289 \\
(0.359)\end{array}$ & $\begin{array}{c}0.366 \\
(0.613)\end{array}$ & $\begin{array}{c}0.735 \\
(0.827)\end{array}$ & $\begin{array}{c}1.251 \\
(0.942)\end{array}$ & $\begin{array}{c}0.119 \\
(0.154)\end{array}$ & $\begin{array}{l}-0.096 \\
(0.060)\end{array}$ \\
\hline $\begin{array}{l}\text { Post GQ upgrades * } \\
\text { District } 0-10 \mathrm{~km} \text { from GQ }\end{array}$ & $\begin{array}{c}0.095 \\
(0.117)\end{array}$ & $\begin{array}{l}-0.031 \\
(0.136)\end{array}$ & $\begin{array}{c}0.159 \\
(0.181)\end{array}$ & $\begin{array}{c}0.368 \\
(0.180)\end{array}$ & $\begin{array}{c}0.404 \\
(0.255)\end{array}$ & $\begin{array}{c}0.855 \\
(0.372)\end{array}$ & $\begin{array}{c}0.165 \\
(0.095)\end{array}$ & $\begin{array}{c}0.077 \\
(0.043)\end{array}$ \\
\hline $\begin{array}{l}\text { Post GQ upgrades * } \\
\text { District } 10-50 \mathrm{~km} \text { from GQ }\end{array}$ & $\begin{array}{l}-0.020 \\
(0.130)\end{array}$ & $\begin{array}{l}-0.060 \\
(0.136)\end{array}$ & $\begin{array}{c}0.012 \\
(0.192)\end{array}$ & $\begin{array}{l}-0.048 \\
(0.244)\end{array}$ & $\begin{array}{l}-0.074 \\
(0.364)\end{array}$ & $\begin{array}{l}-0.282 \\
(0.545)\end{array}$ & $\begin{array}{c}0.043 \\
(0.132)\end{array}$ & $\begin{array}{l}-0.008 \\
(0.074)\end{array}$ \\
\hline \multicolumn{9}{|c|}{ Effects for districts based upon distance from the NS-EW network: } \\
\hline $\begin{array}{l}\text { Post GQ upgrades * } \\
\text { Nodal district NS-EW }\end{array}$ & $\begin{array}{c}0.397 \\
(0.434)\end{array}$ & $\begin{array}{c}0.712 \\
(0.486)\end{array}$ & $\begin{array}{c}0.653 \\
(0.406)\end{array}$ & $\begin{array}{c}0.389 \\
(0.684)\end{array}$ & $\begin{array}{c}0.584 \\
(0.778)\end{array}$ & $\begin{array}{c}0.507 \\
(0.732)\end{array}$ & $\begin{array}{l}-0.117 \\
(0.143)\end{array}$ & $\begin{array}{c}0.103 \\
(0.073)\end{array}$ \\
\hline $\begin{array}{l}\text { Post GQ upgrades * } \\
\text { District } 0-10 \mathrm{~km} \text { from NS-EW }\end{array}$ & $\begin{array}{l}-0.016 \\
(0.106)\end{array}$ & $\begin{array}{c}0.069 \\
(0.107)\end{array}$ & $\begin{array}{c}0.039 \\
(0.142)\end{array}$ & $\begin{array}{l}-0.290 \\
(0.167)\end{array}$ & $\begin{array}{l}-0.239 \\
(0.260)\end{array}$ & $\begin{array}{l}-0.296 \\
(0.376)\end{array}$ & $\begin{array}{l}-0.031 \\
(0.106)\end{array}$ & $\begin{array}{l}-0.055 \\
(0.050)\end{array}$ \\
\hline $\begin{array}{l}\text { Post GQ upgrades * } \\
\text { District } 10-50 \mathrm{~km} \text { from NS-EW }\end{array}$ & $\begin{array}{c}0.006 \\
(0.142)\end{array}$ & $\begin{array}{l}-0.050 \\
(0.143)\end{array}$ & $\begin{array}{l}-0.162 \\
(0.183)\end{array}$ & $\begin{array}{l}-0.230 \\
(0.214)\end{array}$ & $\begin{array}{l}-0.285 \\
(0.310)\end{array}$ & $\begin{array}{l}-0.225 \\
(0.499)\end{array}$ & $\begin{array}{l}-0.094 \\
(0.121)\end{array}$ & $\begin{array}{l}-0.018 \\
(0.058)\end{array}$ \\
\hline District and year fixed effects & Yes & Yes & Yes & Yes & Yes & Yes & Yes & Yes \\
\hline Observations & 1248 & 1248 & 1248 & 1248 & 1248 & 1248 & 1248 & 1244 \\
\hline
\end{tabular}

Notes: See Table 4. 
Appendix Table 2: Industry-level traits for India's manufacturing sector

\begin{tabular}{|c|c|c|}
\hline & $\begin{array}{l}\text { Total establishment } \\
\text { counts, } 2000\end{array}$ & $\begin{array}{l}\text { Land and building } \\
\text { intensity, } 2000\end{array}$ \\
\hline 15 Food products and beverages & $2,962,970$ & 0.03 \\
\hline 16 Tobacco products & $2,062,543$ & 0.03 \\
\hline 17 Textiles & $2,239,348$ & 0.09 \\
\hline 18 Wearing apparel; dressing and dyeing of fur & $2,785,199$ & 0.04 \\
\hline 19 Leather tanning; luggage, handbags, footwear & 171,759 & 0.05 \\
\hline 20 Wood and wood products; straw and plating articles & $2,720,752$ & 0.04 \\
\hline 21 Paper and paper products & 90,214 & 0.07 \\
\hline 22 Publishing, printing, and media reproduction & 144,293 & 0.04 \\
\hline 23 Coke, refined petroleum, and nuclear fuel & 7,429 & 0.03 \\
\hline 24 Chemicals and chemical products & 216,410 & 0.06 \\
\hline 25 Rubber and plastic products & 95,352 & 0.06 \\
\hline 26 Other non-metallic mineral products & 784,551 & 0.09 \\
\hline 27 Basic metals & 43,127 & 0.05 \\
\hline 28 Fabricated metal products, except machinery & 640,256 & 0.04 \\
\hline 29 Machinery and equipment, n.e.c. & 171,138 & 0.05 \\
\hline 30 Office, accounting, and computing machinery & 303 & 0.03 \\
\hline 31 Electrical machinery and apparatus, n.e.c. & 67,896 & 0.07 \\
\hline 32 Radio, television, and comm. equipment & 7,589 & 0.05 \\
\hline 33 Medical, precision and optical instruments, watches & 9,190 & 0.07 \\
\hline 34 Motor vehicles, trailers, and semi-trailers & 24,186 & 0.06 \\
\hline 35 Other transport equipment & 17,495 & 0.06 \\
\hline 36 Furniture, manufacturing n.e.c. & $1,255,784$ & 0.04 \\
\hline Unweighted averages & 750,808 & 0.05 \\
\hline
\end{tabular}

Notes: Descriptive statistics taken from Annual Survey of Industries. 